
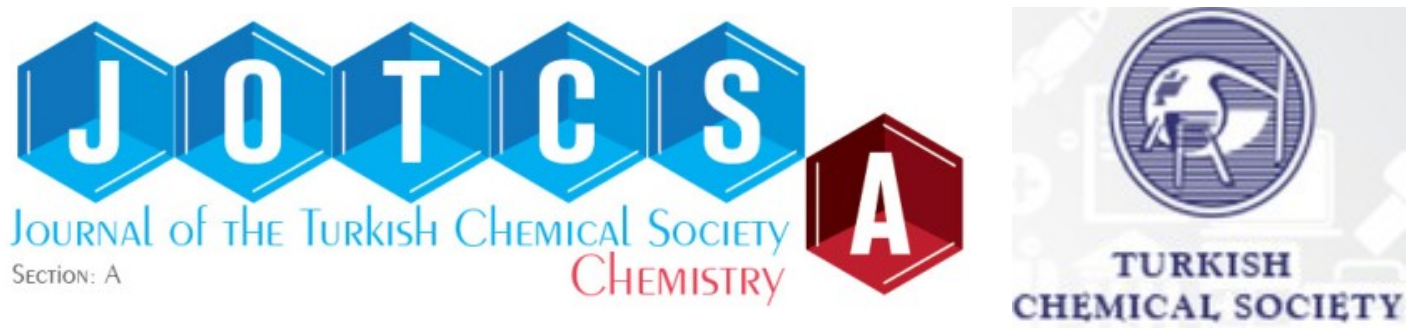

\title{
Traditional Medicinal Uses, Phytochemicals, and Pharmacological Activities of Genus Rhamnus: A review
}

\begin{abstract}
Gashaw Nigussie $^{1,2 *} \square$, Haregua Melak ${ }^{1}$ (D), Milkyas Endale²
${ }^{1}$ Armauer Hansen Research Institute, P.O. Box 1005, Addis Ababa, Ethiopia.

${ }^{2}$ Department of Applied Chemistry, Adama Science and Technology University, P.O. Box 1888, Adama, Ethiopia.

Abstract: The genus Rhamnus belongs to the Rhamnaceae family, which contains approximately 137 species, traditionally used as folk medicine in East Asia, North and South America, and subtropical regions of Africa. The genus is used traditionally to treat diseases such as cancer, wound, jaundice, hepatitis, gonorrhea, laxative, hypertension, malaria, stomach ache, snake bite and diarrhea. Anthraquinones and flavonoids are the most cited compounds from the genus of which polyphenols were abundant with tremendous antioxidant, wound healing and antiinflammatory activities. Pharmacological activity evaluation of the extracts and isolated compounds revealed anti-inflammatory, antioxidant, antimalarial, antibacterial, anti-mutagenic, anti-genotoxic, hepatoprotective, anticancer, and antiproliferative activity. The genus afforded drug leads such as 6-methoxysorigenin (12) and prinoidin (23) with anti-tyrosinase and cytotoxicity, respectively, as well as antioxidant drug leads such as Kaempferol3-O- $\beta$-rhamninoside (31) rhamnetin-3-O- $\beta$-isorhamninoside (37) and isotorachrysone (55). The present review endeavors to provide a comprehensive and up to date compilation of documented traditional medicinal uses, phytochemicals and pharmacological activities of the genus and provided valuable information in support of its uses as an alternative medicine for future healthcare practice.
\end{abstract}

Keywords: Rhamnus, anthraquinones, flavonoids, pharmacological activities.

Submitted: April 28, 2021. Accepted: July 26, 2021.

Cite this: Nigussie G, Melak H, Endale M. Traditional Medicinal Uses, Phytochemicals, and Pharmacological Activities of Genus Rhamnus: A review. JOTCSA. 2021;8(3):899-932.

DOI: https://doi.org/10.18596/jotcsa.929188.

*Corresponding author. E-mail: gashawnigussie20@gmail.com.

\section{INTRODUCTION}

Traditional medicine has been in existence even before the advent of modern medicine. It continues to remain as an alternative care available for the majority of the developing countries due to its intrinsic qualities, unique, and holistic approaches as well as its accessibility and affordability $(1,2)$. The genus Rhamnus consists of 137 species (Figure 1) and 19 synonyms (3). The word Rhamnus means 'a kind of prickly plant' and 'buckthorn or Christ's thorn' in Greek and Latin languages (4). The genus is distributed in East Asia, North and South America and various parts of subtropical Africa with a wide spectrum of traditional medicinal uses (5-13).

The chemistry of Rhamanus species does not exhibit great diversity. The main groups of secondary metabolites reported from the genus are anthrones, anthraquinones, and flavonoids of which polyphenols were abundant with tremendous antioxidant, wound healing, and antiinflammatory activities. The present review endeavors to provide a comprehensive and up-to-date compilation of documented biological activities and phytochemistry of the genus and provided valuable information in support of its uses as an alternative medicine for future healthcare practice. 

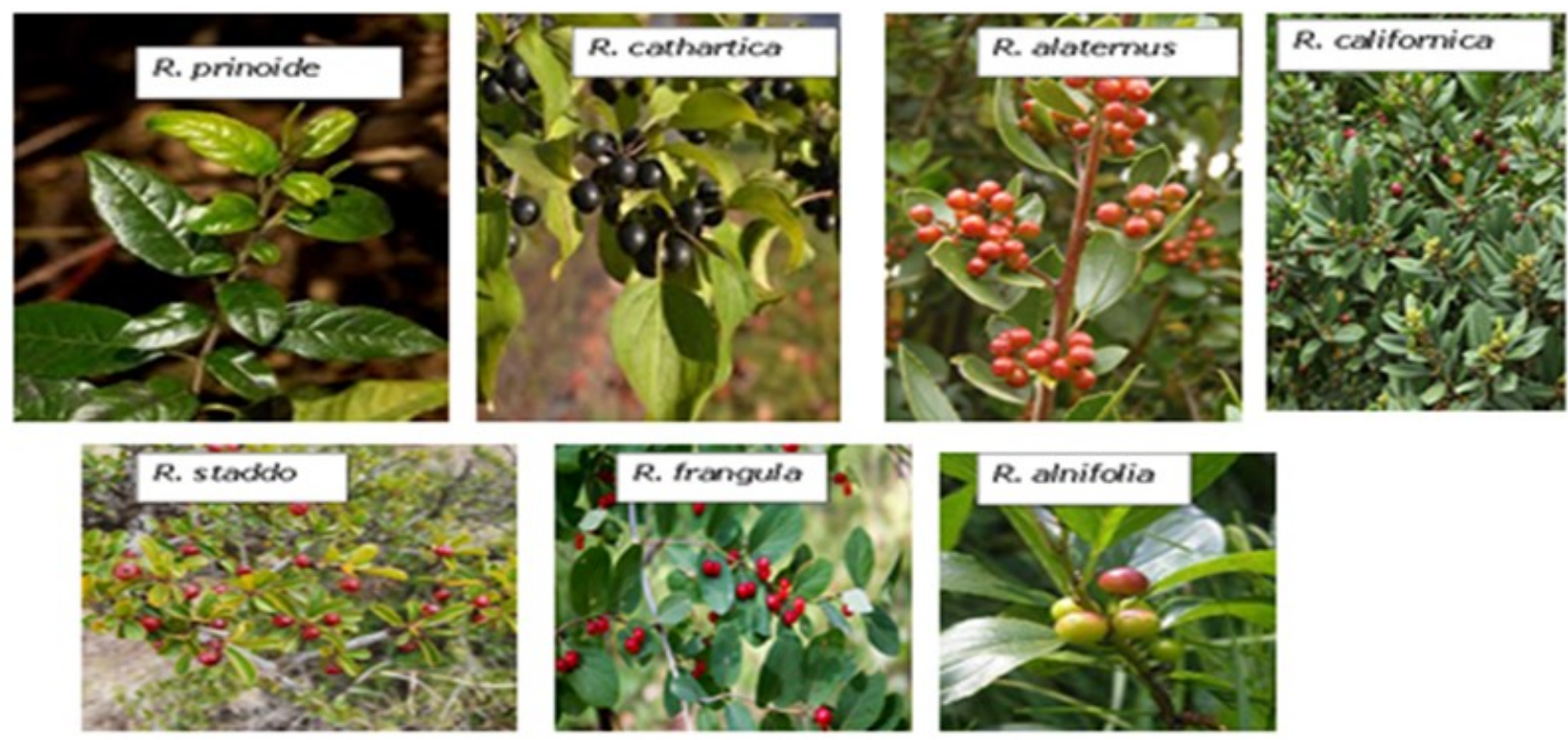

Figure 1: Some medicinally important species of the genus Rhamnus L. $(14,15)$.

\section{Taxonomy of the genus Rhamnus:}

Kingdom: Plantae, Order: Rosales, Family: Rhamnaceae, Genus: Rhamnus. The names redberry, red berry buckthorn, California redberry, evergreen buckthorn, spiny buckthorn, and holly leaf buckthorn have been used for multiple taxa of Rhamnus (16).

\section{Botanical Description and Traditional Uses}

The genus Rhamnus comprises 137 species of shrubs and small trees in temperate, sub-tropical and tropical countries (17). It is an evergreen or deciduous plant and resistant to frost. The leaves are either alternate or sub-opposite. The hermaphrodite small flowers are weakly scented (18). Botanical description and traditional uses of various Rhamnus species is summarized in Table 1 below. 
Table 1: Botanical distribution and traditional medicinal uses of the genus Rhamnus.

\begin{tabular}{|c|c|c|c|c|}
\hline Scientific name & Part & Distribution & Traditional use & Refs \\
\hline \multirow[t]{10}{*}{ R. alaternus L. } & $\begin{array}{l}\text { Leaf, Aerial } \\
\text { Part, }\end{array}$ & Algeria & $\begin{array}{l}\text { as a digestive, diuretic, laxative, and for the therapeutics of } \\
\text { hepatic and dermatological disorders }\end{array}$ & (19) \\
\hline & Leaf & Algeria & treatment of gastrointestinal system diseases (hepatitis) & $(20)$ \\
\hline & Bark & Algeria & Used to treat jaundice & $(21)$ \\
\hline & Aerial part & Algeria & Hepatic jaundice and chlorosis & $(22)$ \\
\hline & Root, Aerial Part & $\begin{array}{l}\text { Spain, Iberian } \\
\text { Peninsula }\end{array}$ & Used to treat depurative (blood purification) & $(23,24)$ \\
\hline & Aerial Part & Spain & therapeutics of hypercholesterolemia & $(23)$ \\
\hline & Aerial Part & Spain & therapeutics of antihypertensive (lowers blood pressure) & $(23)$ \\
\hline & Bark, Branch & Italy & to treat hemostatic, wounds, laxative & $(25)$ \\
\hline & Branch, leaf & Iberian Peninsula & to treat high blood pressure & $(24,26)$ \\
\hline & Branch, Leaf & Israel, Algeria & to treat jaundice & $(5,22)$ \\
\hline R. alnifolia L'Hér & Root, Bark & USA & to treat gonorrhea and cathartic & $(7)$ \\
\hline R. alpina L. & Branch & Italy & to treat cardiac disease, wounds & $(27)$ \\
\hline \multirow[t]{3}{*}{ R. cathartica L. } & Bark & $\begin{array}{l}\text { Bosnia and } \\
\text { Herzegovina, Turkey }\end{array}$ & treatments of common buckthorn, diarrhea, diuretic & $(28,29)$ \\
\hline & Fruit & Southeast Europe & antiseptic for wounds & $(30)$ \\
\hline & Fruit & Serbia & to treat laxative & $(31)$ \\
\hline \multirow[t]{2}{*}{ R. fallax L. } & Bark & $\begin{array}{l}\text { Bosnia and } \\
\text { Herzegovina }\end{array}$ & to treat and manage dermal diseases & $(32,33)$ \\
\hline & Bark & Montenegro/ Serbia & to treat constipation & $(34)$ \\
\hline R. heterophylla Oliver & Root, Leaf & China & to cease bleeding & $(11)$ \\
\hline \multirow[t]{2}{*}{ R. ilicifolia Kellogg } & Root & USA & laxative, diuretic and to treat gonorrhea & $(16)$ \\
\hline & Whole Part & USA & analgesic or antirheumatic & $(35)$ \\
\hline R. Iycioides L. & Leaves, Shoot & Turkey & to treat pulmonary cancer & $(36)$ \\
\hline $\begin{array}{l}\text { R. nepalensis Wall MA } \\
\text { Lawson }\end{array}$ & Root & India & to treat the treatment of pneumonia & $(37)$ \\
\hline R. nitudus Davis & Bark & Turkey & Used as emetic & $(38)$ \\
\hline R. persica Boiss. & Leaf & Iran & to treat allergy and itching in children, wound & (39) \\
\hline \multirow[t]{5}{*}{ R. prinoides L'Hér } & $\begin{array}{l}\text { Bark, Fruit, } \\
\text { Multiple Part }\end{array}$ & Kenya & to treat sexually transmitted disease (gonorrhea), & $(40)$ \\
\hline & $\begin{array}{l}\text { Fruit, Stem, } \\
\text { Root, and Leaf }\end{array}$ & Kenya & to treat gonorrhea, prostate, malaria, brucellosis & $(41)$ \\
\hline & Root & Kenya & $\begin{array}{l}\text { to treat muscular skeleton disorder (Arthritis, backaches, } \\
\text { rheumatic) }\end{array}$ & $(42)$ \\
\hline & Leaf & Ethiopia & to treat Snakebite & $(43)$ \\
\hline & Roots, Leaf & South Africa & Used for blood purifiers, pneumonia, emetics, purgative, colic, & $(44)$ \\
\hline
\end{tabular}




\begin{tabular}{|c|c|c|c|c|}
\hline \multicolumn{5}{|c|}{ stimulants } \\
\hline & Branch & South Africa & Herpes, diabetes, HIV related infections & $(45)$ \\
\hline & $\begin{array}{l}\text { Root, Leaf, and } \\
\text { Steam }\end{array}$ & Kenya & to treat ear, nose, and throat (ENT) diseases & $(46)$ \\
\hline & Leaf & Ethiopia, Uganda & $\begin{array}{l}\text { to treat tonsillitis, wound, eczema, skin infection, fever in children, } \\
\text { tuberculosis, dandruff, water-borne disease }\end{array}$ & $(47-56)$ \\
\hline & Seed & Ethiopia & to treat ringworm & $(57)$ \\
\hline & Root & Kenya & to treat sexually transmitted infection & $(58)$ \\
\hline & Root & Kenya & amoebiasis, bacillary dysentery, tonic, pneumonia & $(59)$ \\
\hline & Root & Ethiopia & to treat hepatic problems & $(60)$ \\
\hline R. purpureus Edgew. & $\begin{array}{l}\text { Bark, Steam, } \\
\text { Fruit, Leaf }\end{array}$ & Himalayas & to treat digestive disorders & $(61,62)$ \\
\hline \multirow[t]{2}{*}{ R. purshiana DC. } & Bark & Algeria & to treat respiratory tract diseases (pharyngitis) & $(20)$ \\
\hline & shell & Mexico & to treat skin rash and stomachache & (63) \\
\hline \multirow[t]{3}{*}{ R. staddo A.Rich } & Tree & Kenya & $\begin{array}{l}\text { Used for strength/nutrient supplement, sexually transmitted } \\
\text { diseases, flu/cold }\end{array}$ & $(64)$ \\
\hline & Multiple Part & Kenya & to treat diarrhea & $(40)$ \\
\hline & Root, Steam, & Kenya & to treat gonorrhea, diabetes, endometritis & $(41)$ \\
\hline \multirow[t]{2}{*}{$\begin{array}{l}\text { R. triqueter Wall M. A. } \\
\text { Lawson }\end{array}$} & $\begin{array}{l}\text { Leaf, Fruit, } \\
\text { Branch }\end{array}$ & Pakistan & to treat hemorrhagic septicemia & $(65)$ \\
\hline & Bark, Fruit & Himalaya & used for blood purifier, boils, scabies, skin diseases, tonic & $(62)$ \\
\hline \multirow[t]{4}{*}{ R. virgatus Roxb. } & Bark & Himalaya, India & to treat eczema and ringworms & $(61,66)$ \\
\hline & $\begin{array}{l}\text { Steam, Fruit, } \\
\text { Bark }\end{array}$ & Himalaya & to treat emetic, purgative, eczema, ringworm, affection of spleen & $(62)$ \\
\hline & Fruit and Bark & Nepal/Iran & to treat diarrhea and dysentry & $(67)$ \\
\hline & Fruit, Bark & India & $\begin{array}{l}\text { to treat emetic, spleen infection, and purgative, curing white dots } \\
\text { of eyes }\end{array}$ & $(61,68)$ \\
\hline
\end{tabular}




\section{Phytochemicals}

Anthraquinones, flavonoids, naphthalene derivatives, terpenoids, alkaloids, steroids, organic acids are secondary metabolites reported from various Rhamnus species of which anthraquinones and flavonoids are the most cited ones (Figures 24, Table 2).

\section{Anthraquinones}

Several anthraquinones (1-30, Table 2) have been isolated from Rhamnus species. Of these, compounds, a cytotoxic compound prinoidin (23) was reported from the fruits of $R$. nepalensis against KB (human epidermoid carcinoma of the mouth) with $\mathrm{IC}_{50}$ value of $0.045 \mu \mathrm{M}$, which was four times more potent than the standard doxorubicin having $\mathrm{IC}_{50}$ value of $0.2 \mu \mathrm{M}$ (69). A prominent anti-tyrosinase effect was displayed by 6-methoxysorigenin (12) reported from $R$. nakaharai with $\mathrm{IC}_{50}$ vaue of $42.2 \mu \mathrm{M}$, which was twofold more potent than kojic acid with $\mathrm{IC}_{50}$ value of $82.1 \mu \mathrm{M}$ (70). In a related study, antioxidant alaternin (10) was reported from $R$. nakaharai with $\mathrm{IC}_{50}$ value of $117.7 \mu \mathrm{M}$ compared to ascorbic acid ( $\mathrm{IC}_{50}$ value of $63.7 \mu \mathrm{M}$ ) using $\mathrm{DPPH}$ assay method (70).

\section{Flavonoids}

Flavonoids, which are important secondary metabolites, are widespread in the plant kingdom, either in a free form or in the form of glycosides with wide spectrum of pharmacological application (71). Various flavonoids (31-52) and their derivatives have been reported from the genus Rhamnus. Of these, flavonoids 31, 33, 36, 37 and 40 exhibited cytotoxic, antioxidant, antihyperlipidemia, anti-proliferative, and antigenotoxic activity (72-75).

\section{Naphthalene derivatives}

To date, 7 naphthalene derivatives (53-59) have been reported from different parts of Rhamnus species such as $R$. prinoides, $R$. cathartica, $R$. wightii, R. procumbens, R. makaharai, R. pallasri and $R$. serrutu. Of these, musizen (54) obtained from whole part of $R$. wightii exhibited antibacterial activities against $S$. aureus and $K$. pneumonia using agar disc diffusion assay with MIC value of 9 $\mu \mathrm{g} / \mathrm{mL}$, which was more potent than streptomycin having MIC value of $120 \mu \mathrm{g} / \mathrm{mL}$ (76).

\section{Terpenoids}

Up to date, four terpenoids (60-63) have been reported from leaves and bark extracts of $R$. califormica (77).

\section{Alkaloids}

Alkaloids are a large group of naturally occurring compounds with diverse pharmacological activity (78). To date, four alkaloids (64-67) have been reported from leaves and bark extracts of $R$. califormica (77).

\section{Steroids}

Previous studies reported limited number of steriods and steriod glycosides such as $\beta$-sitosterol (68) from roots of $R$. formosana, root bark and leaves of $R$. alaternus and leaves of $R$. serrutu (7981) whereas stigmasterol- $\beta$-D-glycoside (69) and $\beta$-sitosterol-3-O-glycoside (70) were reported roots of $R$. formosana (79) and root bark and leaves of $R$. alaternus (80), respectively.

\section{Organic acids}

Organic acids are another important component of the genus Rhamnus. Previously studied revealed compounds 71-72 and 73-75 from leaves of $R$. alaternus (82) and leaves of $R$. heterophylla (83), respectively.

\section{Miscellaneous Compounds}

Compounds $\mathbf{7 6}$ and $\mathbf{7 7}$ were reported from root and bark of $R$. serrutu and $R$. davurica, respectively $(81,84)$. The later was also reported from heart wood parts of $R$. nakaharai (70). 
Table 2: Compounds reported from the genus Rhamnus.

\begin{tabular}{|c|c|c|c|}
\hline Compound & Plant species & Part used & Reference \\
\hline \multicolumn{4}{|l|}{ Anthraquinones } \\
\hline \multirow[t]{8}{*}{ Chryisophanol (1) } & R.formosana and $R$. serrata & Root & $(79,81)$ \\
\hline & R.prinoides & Leaves, Stem & $(85)$ \\
\hline & R.alaternus & Stem, bark & $(86)$ \\
\hline & R.frangula & $\begin{array}{l}\text { Stem bark and } \\
\text { branch }\end{array}$ & $(87)$ \\
\hline & R.sphaerosperma & Stem & $(88)$ \\
\hline & R.alpinus and R.saxatilis & Bark & $(89-91)$ \\
\hline & R.nepalensis & Fruit & (69) \\
\hline & R.californica & Leaf and bark & $(77)$ \\
\hline \multirow[t]{11}{*}{ Emodin (2) } & R.formosanaand R. serrata & Root & $(79,81)$ \\
\hline & R.pumila & Stem,bark & $(86)$ \\
\hline & R.prinoides & Fruit, Leaf & $(92,93)$ \\
\hline & $\begin{array}{l}\text { R.cathartica, } R . \text { pubescens, } \\
R . \quad \text { alaternus and } \\
R . \text { heterophylla }\end{array}$ & Leaf & $(83,94-96)$ \\
\hline & R.frangula & $\begin{array}{l}\text { Stem bark and } \\
\text { branch }\end{array}$ & $(87)$ \\
\hline & R.sphaerosperma & Stem & $(88)$ \\
\hline & R.procumbens & Whole part & $(97)$ \\
\hline & R.alpinus and R.saxatilis & Bark & $(89,90)$ \\
\hline & R.nakaharai & heartwood & $(70)$ \\
\hline & R.nepalensis & Fruit & (69) \\
\hline & R.californica & Leaf and bark & $(77)$ \\
\hline \multirow[t]{5}{*}{ Physcion (3) } & R.formosana & Root & $(79)$ \\
\hline & R.fallax & Stem, bark & $(86)$ \\
\hline & R.intermedia & Stem & $(86)$ \\
\hline & R.prinoides & Leaf and Stem & $(85,92)$ \\
\hline & R.frangula & $\begin{array}{l}\text { Stem bark and } \\
\text { branch }\end{array}$ & $(87)$ \\
\hline
\end{tabular}




\begin{tabular}{|c|c|c|c|}
\hline & $\begin{array}{l}\text { R.serrate, R.alaternus and } R . \\
\text { alaternus }\end{array}$ & Root & $(81,98)$ \\
\hline & R.sphaerosperma & Stem & $(88)$ \\
\hline & $\begin{array}{l}\text { R.davurica, R.alpinus and } \\
\text { R.saxatilis }\end{array}$ & Bark & $(84,89,91)$ \\
\hline & R.procumbens & Whole part & (97) \\
\hline & R.nepalensis & Fruit & (69) \\
\hline & R.californica & Leaf and bark & $(77)$ \\
\hline Emodinanthrone (4) & R.prinoides & Leaves, Stem & $(85,93)$ \\
\hline \multirow[t]{2}{*}{ Emodinbianthrone (5) } & R.prinoides & Fruits & (93) \\
\hline & R.nepalensis & Fruit & (69) \\
\hline $\begin{array}{l}\text { Chrysophanol-emodinbianthrones } \\
\text { (6) }\end{array}$ & R.nepalensis & Fruit & (69) \\
\hline Chrysophanolbianthrone (7) & R.nepalensis & Fruit & $(69)$ \\
\hline $\begin{array}{l}1,2,6,8 \text {-tetrahydroxy-3- } \\
\text { methylanthraquinone-8-O- } \beta \text { - } \\
\text { glucopyranoside }(\mathbf{8})\end{array}$ & R.nakaharai & heartwood & $(70)$ \\
\hline emodin-8-O- $\beta$-glucopyranoside (9) & R.nakaharai & heartwood & $(70)$ \\
\hline Alaternin (10) & R.nakaharai & heartwood & $(70)$ \\
\hline $\begin{array}{l}\text { 6-methoxysorigenin-8-O- } \beta \text { - } \\
\text { glucopyranoside (11) }\end{array}$ & R.nakaharai & heartwood & (70) \\
\hline 6-methoxysorigenin (12) & R.nakaharai & heartwood & (70) \\
\hline \multirow[t]{2}{*}{ Aloe-emodin (13) } & R.alaternus & Root & $(98)$ \\
\hline & R.alpinus and R.saxatilis & Bark & $(89-91)$ \\
\hline \multirow[t]{2}{*}{ Rhein (14) } & R.alaternus & Root & $(98)$ \\
\hline & R.alpinus and R.saxatilis & Bark & $(89-91)$ \\
\hline \multirow[t]{2}{*}{ Madagascin (15) } & R.saxatilis and $R$. alpinus & Bark & $(90)$ \\
\hline & $\begin{array}{lll}\begin{array}{l}\text { R.cathartica } \\
\text { intermedia }\end{array} & \text { and } & R . \\
\end{array}$ & Fruit & (99) \\
\hline 3-geranyloxyemodin (16) & R.saxatilis and R. alpinus & Bark & $(90)$ \\
\hline $\begin{array}{l}\text { emodin-6-O-arabinopyranoside- } \\
\text { 3', }^{\prime} \text {-diacetate (17) }\end{array}$ & R.alaternus & Fruit & $(100)$ \\
\hline $\begin{array}{l}\text { emodin-6-O-arabinopyranoside- } \\
2^{\prime}, 3^{\prime}, 4^{\prime} \text {-triacetate }(\mathbf{1 8})\end{array}$ & R.alaternus & Fruit & $(100)$ \\
\hline Emodin 6-O- $\beta$-L-rhamnose (19) & R.libanoticus & Bark & $(101)$ \\
\hline Emodin 8-O- $\beta$-D-glucoside (20) & R.libanoticus & Bark & $(101)$ \\
\hline
\end{tabular}




\begin{tabular}{|c|c|c|c|}
\hline \multirow[t]{2}{*}{ Physcion 8-O- $\beta$-rutinoside (21) } & R.libanoticus & Bark & $(101)$ \\
\hline & R.pallasri & Bark & $(102)$ \\
\hline $\begin{array}{l}\text { Emodinanthrone-6-O- } \\
\text { rhamnopyranoside--2', } 3^{\prime}, 4^{\prime}- \\
\text { triacetate }(\mathbf{2 2})\end{array}$ & R.prinoides & Fruit & (93) \\
\hline Prinoidin (23) & R.prinoides & Fruit & $(85,93)$ \\
\hline Prinoidin-emodinbianthrones (24) & R. nepalensis & Fruit & (69) \\
\hline Rhamnepalins (25) & R. nepalensis & Fruit & (69) \\
\hline \multirow[t]{2}{*}{ Glucofrangulin (26) } & R.prinoides & Fruit & (103) \\
\hline & R.cathartica & Leaf & $(94)$ \\
\hline $\begin{array}{l}\text { 1,6,8-trihydroxy-3- } \\
\text { methylanthraquinone } \quad 1 \\
\text { rhamnosyl }(1 \rightarrow 2) \text { glucoside }(\mathbf{2 7})\end{array}$ & R.formosana & Root & (104) \\
\hline $\begin{array}{l}\text { 1,8-dihydroxy-6-methoxy-3- methyl } \\
\text { anthraquinones 8-0- rhamnosyl- } \\
(1 \rightarrow 2) \text {-glucoside }(\mathbf{2 8})\end{array}$ & R.formosana & Root & (79) \\
\hline $\begin{array}{lr}1,2,6,8 \text { tetrahydroxy-3 } & \text { methyl } \\
\text { anthraquinone } & 8-O-B-D- \\
\text { glucopyranoside (29) } & \\
\end{array}$ & R.alaternus & Root bark and Leaf & $(80)$ \\
\hline $\begin{array}{l}1,4,6,8 \text { tetrahydroxy-3 methyl } \\
\text { anthraquinones } 1-O-B-D- \\
\text { glucopyranosyl-4,6-di-O-a-L- } \\
\text { rhamnopyranoside }(\mathbf{3 0})\end{array}$ & R.alaternus & Root bark and Leaf & $(80)$ \\
\hline \multicolumn{4}{|l|}{ Flavonoids } \\
\hline \multirow{3}{*}{$\begin{array}{l}\text { Kaempferol-3-O- } \beta \text {-rhamninoside } \\
\text { (31) }\end{array}$} & R.petiolaris & Fruit & $(105)$ \\
\hline & R. nakaharai & Heartwood & $(70)$ \\
\hline & R. alaternus & Leaf & $(72,73)$ \\
\hline \multirow[t]{2}{*}{ Luteolin (32) } & R.alaternus & Leaf & $(82)$ \\
\hline & R.davurica & Bark & $(84)$ \\
\hline \multirow[t]{6}{*}{ Kaempferol (33) } & R.alaternus & Leaf, Fruit & $(96,106)$ \\
\hline & R.lycioides & Aerial parts & $(107)$ \\
\hline & R.davurica & Bark & $(84)$ \\
\hline & $\begin{array}{l}\text { R.saxatilis, R.catharticus and } \\
\text { R.disperma }\end{array}$ & Fruit & (106) \\
\hline & R.californica & Leaf and bark & $(77)$ \\
\hline & R.pallasii & Bark & $(108)$ \\
\hline
\end{tabular}




\begin{tabular}{|c|c|c|c|}
\hline & R.heterophylla & Leaf & $(83)$ \\
\hline \multirow[t]{5}{*}{ Quercetin (34) } & R.lycioides & Aerial part & $(107)$ \\
\hline & R.pallasii and R.davurica & Bark & $(84)$ \\
\hline & $\begin{array}{l}\text { R.saxatilis, R.catharticus, } \\
\text { R.alaternus and R.disperma }\end{array}$ & Fruit & $(106)$ \\
\hline & R.californica & Leaf and bark & $(77)$ \\
\hline & R.heterophylla & Leaf & $(83)$ \\
\hline Rhamnazin-3- isorhamninoside (35) & R.formosana & Root & $(104)$ \\
\hline \multirow{3}{*}{$\begin{array}{l}\text { Rhamnocitrin 3-O- } \beta \text {-isorhamninoside } \\
\text { (36) }\end{array}$} & R.formosana & Root & $(104)$ \\
\hline & R.nakaharai & heartwood & $(70)$ \\
\hline & R. alaternus & Leaf & $(72,73)$ \\
\hline $\begin{array}{l}\text { Rhamnetin 3-O-isorhamninoside } \\
\text { (37) }\end{array}$ & R. alaternus & Leaf & $(72,73)$ \\
\hline $\begin{array}{l}\text { Rhamnetin 3-O-(3"'"-O- } \beta \text { - } \\
\text { coumaroyl)- } \beta \text { - rhamninoside (38) }\end{array}$ & R.petiolaris & Fruit & $(105)$ \\
\hline \multirow{2}{*}{ Quercitrin 39) } & R.petiolaris & Fruit & $(105)$ \\
\hline & R.pallnsii & Bark & $(108)$ \\
\hline Apigenin (40) & R.davurica & Bark & $(84)$ \\
\hline \multirow[t]{2}{*}{ Rutin (41) } & R.alaternus & Leaf & $(82)$ \\
\hline & R.cathartica & Leaf & $(94)$ \\
\hline \multirow[t]{4}{*}{ Rhamnazin (42) } & R.prinoides & Fruits, Leaf & $(93)$ \\
\hline & R.lycioides & Arial part & $(107)$ \\
\hline & R.disperma & Arial part & $(109)$ \\
\hline & R.heterophylla & Leaf & $(83)$ \\
\hline \multirow[t]{2}{*}{ Rhamnetin (43) } & R.lycioides & Arial Part & $(107)$ \\
\hline & R.disperma & Fruit & $(70)$ \\
\hline \multirow[t]{2}{*}{ Aromadendrin (44) } & R.lycioides & Arial Part & $(110)$ \\
\hline & R.pallasii & Bark & $(108)$ \\
\hline \multirow[t]{2}{*}{ Eriodictyol (45) } & R.lycioides & Arial Part & $(110)$ \\
\hline & R.pallasii & Bark & $(108)$ \\
\hline \multirow[t]{4}{*}{ Rhamnocitrin (46) } & R.prinoides & Leaf and Stem & (93) \\
\hline & R.lycioides & Arial Part & $(107)$ \\
\hline & R.davurica & Bark & $(84)$ \\
\hline & R.saxatilis & Fruit & $(106)$ \\
\hline
\end{tabular}




\begin{tabular}{|c|c|c|c|}
\hline & R.catharticus & Fruit & $(106)$ \\
\hline & R.alaternus & Fruit & $(106)$ \\
\hline & R.heterophylla & Leaf & $(83)$ \\
\hline \multirow[t]{4}{*}{ Taxifolin (47) } & R.lycioides & Arial Part & (107) \\
\hline & R.pallnsii & Bark & $(108)$ \\
\hline & R.davurica & Bark & $(84)$ \\
\hline & R.pallasii & Bark & (108) \\
\hline 3- methoxy flavone (48) & R.lycioides & Aerial part & (107) \\
\hline 3-O-Methylquercetin (49) & R.prinoides & Leaf and Stem & $(93)$ \\
\hline Pallasiin (50) & R.pallasii & Bark & $(108)$ \\
\hline Isorhamnetin (51) & R.pallasii & Bark & $(108)$ \\
\hline Mearnsetin (52) & R.pallasii & Bark & $(108)$ \\
\hline \multicolumn{4}{|l|}{ Naphthalene Derivatives } \\
\hline \multirow{2}{*}{$\begin{array}{l}\text { Geshoidin (P-sorigenin-8-O- } \beta \text {-D- } \\
\text { glucoside) (53) }\end{array}$} & R.prinoides & Leaf and stem & $(85)$ \\
\hline & R. cathartica & Leaf & \\
\hline \multirow[t]{2}{*}{ Musizin (54) } & R.prinoides & Leaf and stem & $(85)$ \\
\hline & R.wightii and $R$. procumbens & Whole part & $(76,97)$ \\
\hline Isotorachrysone (55) & R.nakaharai & Root bark & $(111)$ \\
\hline \multirow[t]{2}{*}{$\beta$-sorigenin (56) } & R.prinoides & Leaf and stem & $(85)$ \\
\hline & R. cathartica & Leaf & $(94)$ \\
\hline a-sorinin (57) & R.pallasri & Bark & $(102)$ \\
\hline Eugenine (58) & R.serrutu & Root & $(81)$ \\
\hline 3-hydroxyeugenine (59) & R.serrutu & Root & $(81)$ \\
\hline \multicolumn{4}{|l|}{ Terpenoids } \\
\hline Umbellulone (60) & R.californica & Leaf and bark & $(77)$ \\
\hline 1,8-cineole (61) & R.californica & Leaf and bark & $(77)$ \\
\hline a-terpineol (62) & R.californica & Leaf and bark & $(77)$ \\
\hline Thymol (63) & R.californica & Leaf and bark & $(77)$ \\
\hline \multicolumn{4}{|l|}{ Alkaloid } \\
\hline Domesticine (64) & R.californica & Leaf and bark & $(77)$ \\
\hline Nordomesticine (65) & R.californica & Leaf and bark & $(77)$ \\
\hline
\end{tabular}




\begin{tabular}{|c|c|c|c|}
\hline Isoboldine (66) & R.californica & Leaf and bark & (77) \\
\hline Bufotenine (67) & R.californica & Leaf and bark & (77) \\
\hline \multicolumn{4}{|l|}{ Steroids } \\
\hline Stigmasterol- $\beta$-D-glycoside (68) & R.formosana & Root & (79) \\
\hline \multirow[t]{3}{*}{$\beta$-sitosterol (69) } & R.formosana & Root & (79) \\
\hline & R.alaternus & Root bark and Leaf & $(80)$ \\
\hline & R.serrutu & Leaf & (81) \\
\hline$\beta$-sitosterol-3-O-glycoside (70) & R.alaternus & Root bark and Leaf & (80) \\
\hline \multicolumn{4}{|l|}{ Organic Acid } \\
\hline P-coumaric acid (71) & R.alaternus & Leaf & $(82)$ \\
\hline Ferulic acid (72) & R.alaternus & Leaf & (82) \\
\hline \multirow[t]{2}{*}{ Gallic acid (73) } & R.alaternus & Leaf & $(82)$ \\
\hline & R.heterophylla & Leaf & $(83)$ \\
\hline Malic acid (74) & R.heterophylla & Leaf & $(83)$ \\
\hline Salicylic acid (75) & R.heterophylla & Leaf & $(83)$ \\
\hline \multicolumn{4}{|l|}{ Miscellaneous Compounds } \\
\hline \multirow[t]{2}{*}{ 5-hydroxy-7-methoxyphtali (76) } & R.serrutu & Root & $(81)$ \\
\hline & R.davurica & Bark & (84) \\
\hline p-hydroxybenzaldehyde (77) & R. nakaharai & Heart wood & $(70)$ \\
\hline
\end{tabular}


<smiles>[R]Oc1cc(O)cc2c1C(=O)c1c(cc(C)c([R])c1O)C2=O</smiles><smiles>[R]Oc1cc(OC)c2c(O)c3c(cc2c1)COC3=O</smiles><smiles>[R]c1cc(O)c2c(c1)C(=O)c1cc([R])cc(O)c1C2=O</smiles>
$10 R^{4}=O H, R^{2}=H$<smiles>[R]c1cc(O)c2c(c1)C(c1cc(C)cc(O)c1)c1cc([R4])cc(O)c1C(=O)c1c(O)cc(O)cc1C2</smiles>

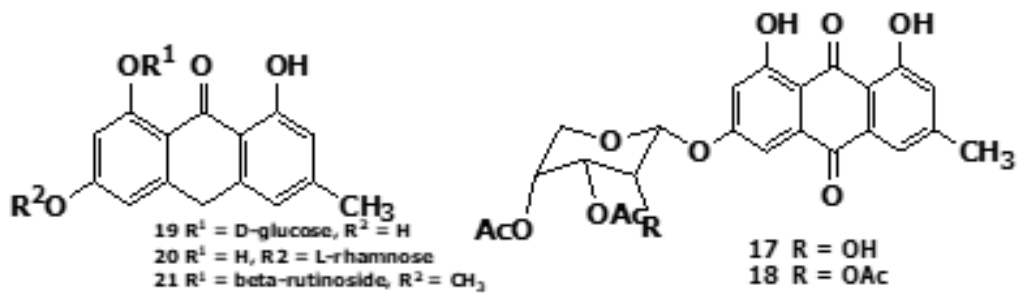<smiles>[R]O[R4]([R])=O</smiles>

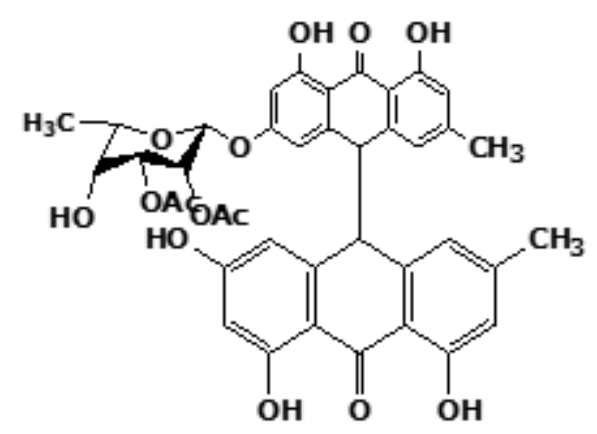

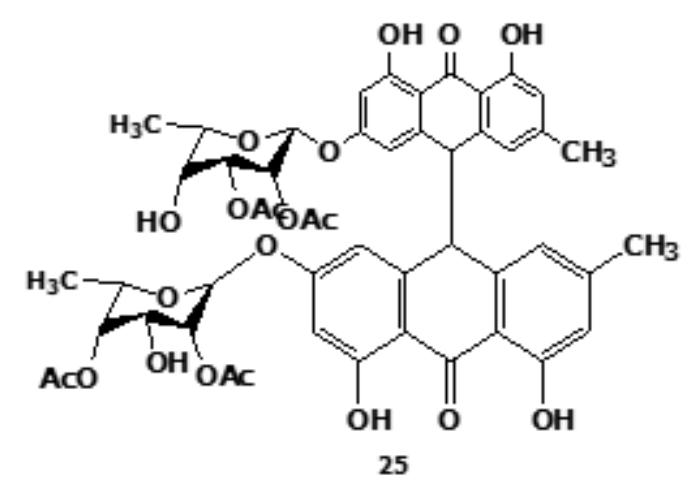

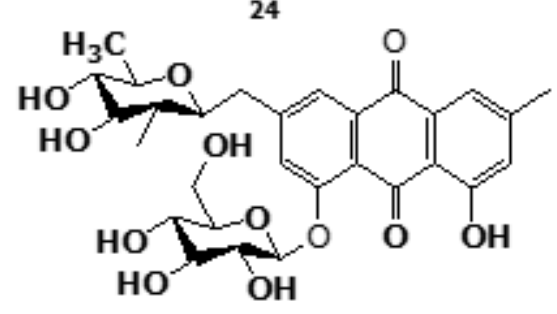<smiles>[R]Oc1cc(C)cc2c1C(=O)c1c(O)cc(O)cc1C2=O</smiles><smiles>[R20]c1cc(OC)c2c(c1)C(=O)c1c(O)cc(C)cc1C2=O</smiles>
$28 R=$ GluORha

26<smiles>[R]c1cc([R])c2c(c1)C(=O)c1c([R])c(C)c([R])c([R])c1C2=O</smiles>

$29 \mathbf{R}^{1}=\mathrm{H}, \mathrm{R}^{2}=\mathrm{OH}, \mathrm{R}^{3}=\mathrm{H}_{,} \mathrm{R}^{4}=\mathrm{OH}, \mathrm{R}^{5}=\mathrm{O}$-glu $30 \mathbf{R}^{1}=$ glu, $\mathbf{R}^{2}=\mathrm{H}, \mathbf{R}^{3}=$ O-rha, $\mathbf{R}^{4}=$ O-rha, $\mathbf{R}^{5}=$ OH

Figure 2: Anthraquinones reported from the genus Rhamnus. 


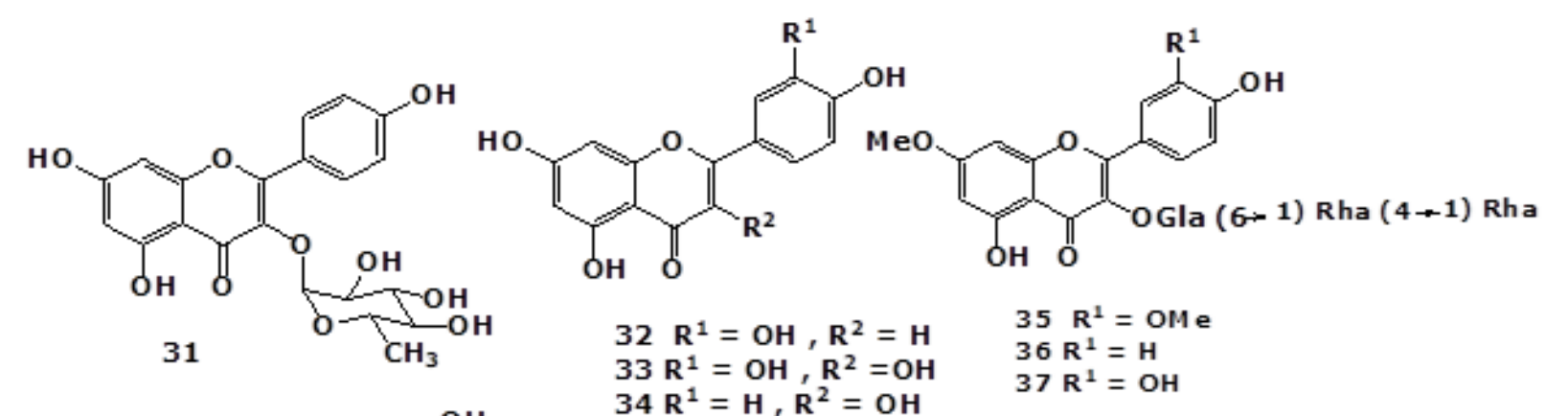

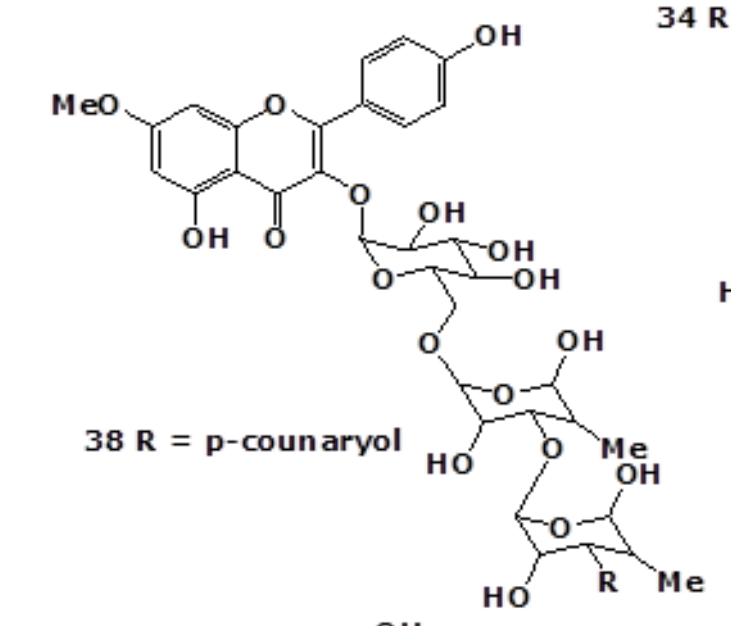<smiles>COc1cc(O)c2c(c1)CC(c1ccc(O)c(O)c1)=C(O)C2=O</smiles><smiles>CC1OC(Oc2c(-c3ccc(O)c(O)c3)oc3cc(O)cc(O)c3c2=O)[C@H](O)[C@H](O)C1O</smiles><smiles>[R]c1cc(C2CC(=O)c3c(O)cc(O)cc3O2)ccc1O</smiles><smiles>COc1cc(O)c2c(c1)CC(c1ccc(O)cc1)=C(O)C2=O</smiles>

41<smiles>COC1OC(O)C(O)C(O)C1O</smiles><smiles>[R3][AsH3]</smiles><smiles>COc1c(-c2ccc(O)c(O)c2)oc2cc(O)cc(O)c2c1=O</smiles><smiles>COc1cc(-c2oc3cc(O)cc(O)c3c(=O)c2O)ccc1O</smiles><smiles>O=C1c2c(O)cc(O)cc2OC(c2ccc(O)c(O)c2)[C@@H]1O</smiles><smiles>O=C1c2c(O)cc(O)cc2OC(c2cc(O)c(O)c(O)c2)C1O</smiles><smiles>COc1c(O)cc(-c2oc3cc(O)cc(O)c3c(=O)c2O)cc1O</smiles>

Figure 3: Flavonoids reported from the genus Rhamnus. 
<smiles>O=C1OCc2cc3cccc(OC(O)[C@H](O)[C@H](O)C(O)CO)c3cc21</smiles><smiles>CC(=O)c1c(C)cc2cccc(O)c2c1O</smiles>

54<smiles>COc1cc(O)cc2cc(C)c(C(=O)O)c(O)c12</smiles>

55<smiles>[R]c1c([N+](=O)O)oc2cc(OC)cc(O)c2c1=O</smiles><smiles>O=C1OCc2cc3cccc(O)c3c(O)c21</smiles>

56

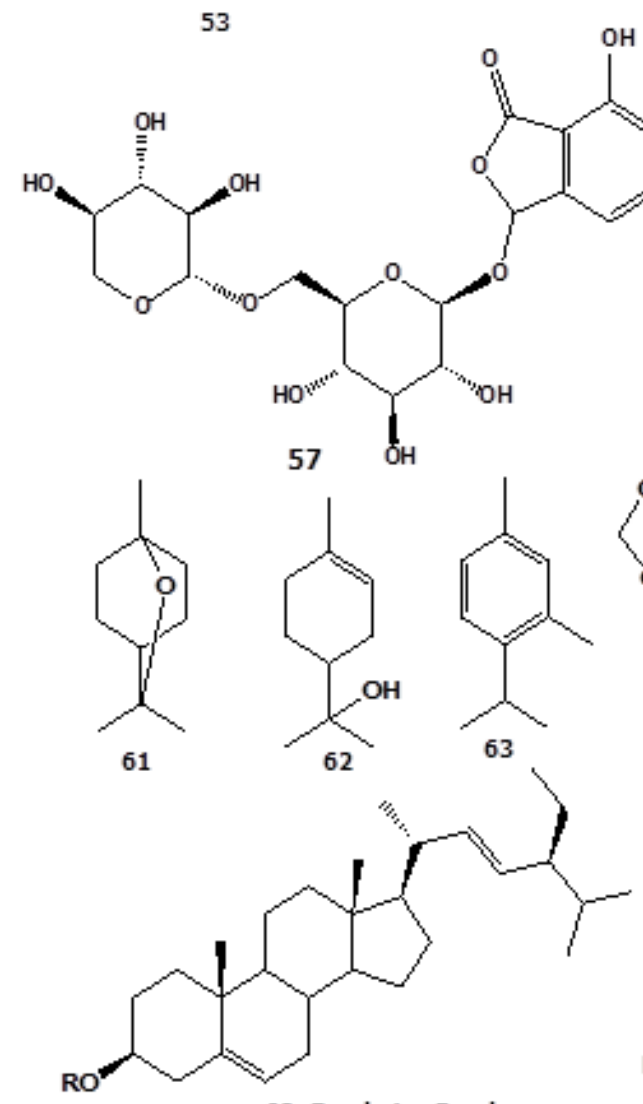

$68 \mathrm{R}=$ beta $-\mathrm{D}-\mathrm{g}$ lucose<smiles></smiles><smiles>CC1=CC(=O)C2(C(C)C)CC12</smiles><smiles>CN(C)CCc1c[nH]c2ccc(O)cc12</smiles>

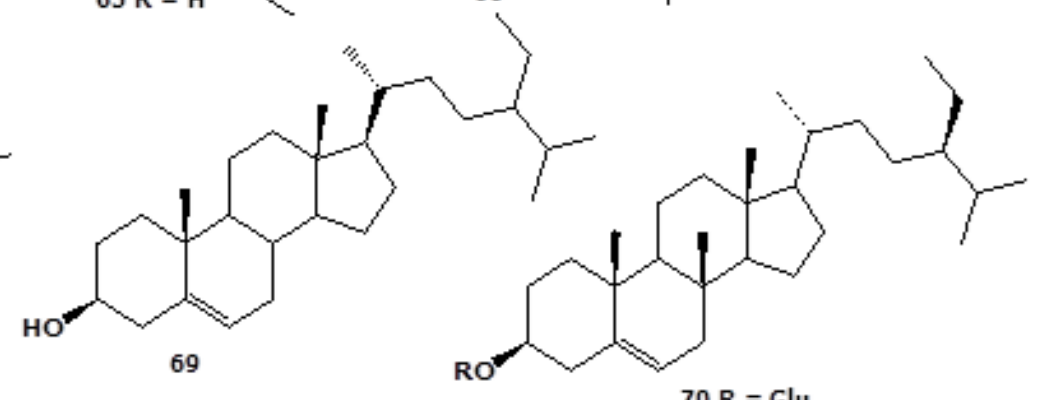<smiles>[R]c1ccc(/C=C/C(=O)O)cc1[R]</smiles>

$71 \mathrm{R}^{1}=\mathrm{H}, \mathrm{R}^{2}=\mathrm{OH}$

$72 \mathrm{R}^{1}=\mathrm{OCH}_{3}, \mathrm{R}^{2}=\mathrm{OH}$<smiles>O=C(O)CC(O)C(=O)O</smiles><smiles>O=C(O)c1ccccc1O</smiles>

73<smiles>COc1cc(O)c2c(c1)COC2=O</smiles><smiles>O=Cc1ccc(O)cc1</smiles>

Figure 4 : Napthalenic derivatives, terpenoids, alkaloids, organic acids and other compounds reported from the genus Rhamnus. 


\section{Essential oils}

The essential oils from plants are known with various pharmacological activities (112). Campbell et al., (2019) reported essential oils from the leaves of R. prinoides of which 4-hydroxy-4methyl-2-pentanone and ethyl 4-ethoxybenzoate score more than $85 \%$ and exhibited significant anti-biofilm activity (113). In a related study, Chouitah et al., (2012) reported essential oils from the leaves of R.alaternus (114) of which camphene (17.63\%), linalool (16.13\%), pulegone (15.01 $\%)$, naphthalene (14.66 \%), mequinol (2.77\%) and borneol $(2.13 \%)$ are among the major components.

\section{Pharmacological activities Hepatoprotective activity}

Berroukche et al. (2015) evaluated hepatoprotective activity of the macerated $R$. alaternus extract in Wistar rats treated with the toxic carbon tetrachloride $\left(\mathrm{CCl}_{4}\right)$ that causes hepatic damage through evaluation of both the biochemical and histopathological changes in rats. The extracts with bodily weight $(250 \mathrm{mg} / \mathrm{kg})$ reduced the elevated levels of alkaline phosphatase (ALP),Glutamic oxaloacetic transaminase (GOT), Glutamic pyruvic transaminase (GPT) and total bilirubin and significantly attenuated the deleterious histopathologic changes in the liver after carbon tetrachloride $\left(\mathrm{CCl}_{4}\right)$-intoxication (14).

\section{Anti-inflammatory activity}

Thakru and Prasad (2019) evaluated in vivo antiinflammatory activity of ethanolic extract of R.purpureus stem bark using the carrageenaninduced rat paw edema assay in adult Swiss albino mice, where $200 \mathrm{mg} / \mathrm{kg}$ bodily weight of the extract was administered orally to different groups of mice with indomethacin $(10 \mathrm{mg} / \mathrm{kg})$ as the positive control. The crude ethanolic extract showed considerable $(P<0.05)$ anti-inflammatory activity with inhibition of $54.50 \%$ and $54.77 \%$ after $3 \mathrm{~h}$ and $4 \mathrm{~h}$ of treatment as compared to the standard drug indomethacin $(10 \mathrm{mg} / \mathrm{kg})$ showed the inhibition of $50.46 \%$, and $51.78 \%$ after $3 \mathrm{~h}$ and $4 \mathrm{~h}$ of treatment, respectively (115).

Chen et al., (2018) evaluated the antiinflammatory activity of apigenin (40) and Kaempferol (33) isolated from $80 \%$ methanol bark extract of R.davurica Pall using the cyclooxygenase (COX-2) inhibition assay, with aspirin as the positive control. Apigenin (40) and Kaempferol (33) exhibited anti-inflammatory activity with IC $_{50}$ values of 10.14 and $9.27 \mu \mathrm{g} / \mathrm{mL}$, respectively (74). Chen et al., (2020) evaluated anti-inflammatory activity of $60 \%$ ethanol stem and stem bark semipurified extracts of R.prinoides using cyclooxygenase (COX-2) inhibition assay, with aspirin as the positive control. The semi-purified extract exhibited activity with IC $_{50}$ value of 20.6 $\mu \mathrm{g} / \mathrm{mL}$, which was weak activity compared to $\mathrm{IC}_{50}$ value of $6.33 \mu \mathrm{g} / \mathrm{mL}$ exhibited by ascorbic acid (116).

\section{Antibacterial activity}

Molla et al., (2016) evaluated antibacterial activities of methanol and chloroform solvent fractions of R.prinoides crude leaves extract against $S$. aureus, S. pyogen, S. pneumoniae, and $S$. typhi using agar well diffusion methods with ampicillin and ciprofloxacin as positive controls. Methanol and chloroform extracts revealed antibacterial activities at different concentrations (78 mg/well, $39 \mathrm{mg} /$ well, and $19.5 \mathrm{mg} /$ well). The average minimum inhibitory concentration of the methanol and chloroform extracts ranged from 8.13-32.5 $\mathrm{mg} / \mathrm{mL}$ and 8.13-16.25 $\mathrm{mg} / \mathrm{mL}$, respectively (117)

Ammar et al., (2007) evaluated the antibacterial activities of petroleum ether, chloroform, ethyl acetate, methanol, and total Oligomers flavonoids (TOF) enriched leaves extracts of $R$.alaternus against S. aureus, E. faecalis, E. coli, S. enteritidis and $S$. typhimurium using micro dilution and agar dilution methods. The TOF extracts showed activities against $S$. aureus, E. faecalis, E. coli, S. enteritidis and $S$. typhimurium with MIC values of $120 \mu \mathrm{g} / \mathrm{mL}, 175 \mu \mathrm{g} / \mathrm{mL}, 1.75 \mu \mathrm{gg} / \mathrm{mL}, 125 \mu \mathrm{g} / \mathrm{mL}$ and $62.5 \mu \mathrm{g} / \mathrm{mL}$, respectively, while the ethyl acetate extract exhibited with MIC values of 70 $\mu \mathrm{g} / \mathrm{mL}, 150 \mu \mathrm{g} / \mathrm{mL}, 3.75 \mathrm{mg} / \mathrm{mL}, 100 \mu \mathrm{g} / \mathrm{mL}$ and $175 \mu \mathrm{g} / \mathrm{mL}$, respectively (118).

Chouitah et al., (2012) evaluated antibacterial activities of essential oils of R.alaternus leaves against $P$. aeroginosa, $E$. coli and $S$. typhimurium using the paper disc diffusion method. The essential oils exhibited activities with zones of inhibition 8, 17 and $15 \mathrm{~mm}$, respectively (114). Carranza et al., (2015) evaluated antibacterial activities of methanol extracts of leaves and bark of $R$. californica against $B$. cereus, $S$. pyogenes, $M$. smegmatis, $S$. aureus, methicillin-resistant $S$. aureus (MRSA), E. coli, and $P$. aeruginosa using disc diffusion and minimal inhibitory concentration (MIC) assays. Both extracts inhibited MRSA growth and other Gram-positive bacteria with MICs of 3.3$6.0 \mathrm{mg} / \mathrm{mL}$ (77). Raja et al., (2018) evaluated antibacterial activities of ethyl acetate extract of $R$.wightii whole part against $S$. aureus, B. cereus, $E$. faecalis, K. pneumonia, $P$. aeruginosa and $E$. coli using agar disc diffusion method with streptomycin and gentamycin as positive controls. The ethyl acetate extract of the whole part of R. wightii revealed inhibition zones (in $\mathrm{mm}$ ) of 15 , $16.66,15,19,10.66$ and 12 , respectively, which is highly comparable with the positive control, streptomycin (25 $\mathrm{\mu g} /$ disc) and gentamycin (50 
$\mu \mathrm{g} /$ disc). The isolated compound musizen (54) and standard drugs have additionally inhibited $S$. aureus and $K$. pneumonia growth at a concentration (MIC value) of $9 \mu \mathrm{g} / \mathrm{mL}$ and 120 $\mu \mathrm{g} / \mathrm{mL}$, respectively (76).

Kosalec et al., (2013) evaluated antibacterial activities of methanol bark extracts of $R$. alaternus, $R$. fallax, $R$. intermedia and $R$. pumila against $S$. aureus, $P$. aeruginosa and $E$. coli using microdilution broth assay. All plant extracts exhibited activities with MIC values of ranging from 1.25 to $2.5 \mu \mathrm{g} / \mathrm{mL}$ (86). Carranza et al., (2015) evaluated antibacterial activities of methanol leaf extracts of R.californica against $S$. aureus, Methicillin-resistant $S$. aureus, $B$. cereus, $P$. aeruginosa, $S$. pyogenes and $E$. coli using Kirby-Bauer disc diffusion assay with streptomycin as positive control. The extract exhibited activities with zone of inhibition ranging from $9 \mathrm{~mm}$ to $14.3 \mathrm{~mm}$, which was moderate activities compared to the standard with zone of inhibition ranging from $17 \mathrm{~mm}$ to $23.8 \mathrm{~mm}$ (77).

\section{Antifungal Activity}

Kosalec et al., (2013) evaluated antibacterial activities of methanol bark extracts of $R$. alaternus, $R$. fallax, $R$. intermedia and $R$. pumila against $C$. albicans, $A$. niger and $M$. gypseum using microdilution broth assay. All the plant extracts exhibited activities with MIC values of 0.625 $\mathrm{mg} / \mathrm{mL}$ and $2.5 \mathrm{mg} / \mathrm{mL}$ against Candida albicans and Aspergillus niger, respectively, whereas extracts of $R$. fallax, $R$. intermedia and $R$. pumila exhibited with MIC value of $0.313 \mathrm{mg} / \mathrm{mL}$ against dermatophyte species (Microsporum gypseum) (86).

\section{Antimalarial activity}

Koch et al. (2009) evaluated antimalarial activities of chloroform root bark extracts of $R$. prinoides against chloroquine-sensitive Plasmodium falciparum strain using ELISA assay with chloroquine as standard drug. The extract exhibit with $\mathrm{IC}_{50}$ value of $3.53 \mu \mathrm{g} / \mathrm{mL}$, which was weak activities compared to IC $_{50}$ value of $0.004 \mu \mathrm{g} / \mathrm{mL}$ exhibited by chloroquine the standard drug (119). Another study evaluated the anti-plasmodia activities of n-hexane, dichloromethane, and methanol root extracts of R.prinoides using the radioisotope method. All extracts were found to have in vitro antimalarial activity. The highest activity was displayed by n-hexane and dichloromethane extracts with IC $_{50}$ values of 19.9 $\mu \mathrm{g} / \mathrm{mL}$ and $30.3 \mu \mathrm{g} / \mathrm{mL}$, respectively (120). The naphthalene derivative geshoidin (53) from R.prinoides showed an $\mathrm{IC}_{50}$ value of $4.0 \mathrm{pM}$ and $0.4 \mathrm{pM}$ against the chloroquine-sensitive (D6) and chloroquine-resistant (W2) strains of Plasmodium falciparum (121). In a related study, in vivo antimalarial activity of aqueous extracts from leaves and root barks of $R$.staddo, $R$. prinoides and their chloroquine (CQ) potential effects against a bloodinduced CQ-resistant rodent parasite in mice showed high chemo suppression in the range $51 \%$ $-75 \%$ (122). Results of those studies suggest that the extracts of R.prinoides have a promising antiplasmodial activity which supports the folkloric use of the plant for treating malaria.

\section{Antioxidant activity}

Bhouri et al., (2011) evaluated Kaempferol 3-O- $\beta$ isorhamninoside (31) and rhamnocitrin 3-O- $\beta$ isorhamninoside (36) isolated from soxhlet methanolic leaves extract of R.alaternus using superoxide radical scavenging activity with riboflavin as reference signal. The compounds produced an $80.4 \%$ and $85.6 \%$ decrease in NBT/riboflavin photo reduction, respectively, at a dose of $150 \mu \mathrm{g} / a s s a y$. However K3O-ir was more potent superoxide scavenger with an $\mathrm{IC}_{50}$ value of $18.75 \mu \mathrm{g} / \mathrm{mL}$ than R30-ir $\left(\mathrm{IC}_{50}=22.5 \mu \mathrm{g} / \mathrm{mL}\right)(73)$. Rocchetti et al., (2019) determined the antioxidant activities of methanol and aqueous unmature fruit extracts of R.petiolaris using radical scavenging activities (DPPH and ABTS assay) with reported as trolox equivalents (mgTE/g extract) as reference. The methanolic and aqueous unmature fruit extracts were the most effective 2,2-diphenyl-1picrylhydrazyl (DPPH) and 2,2'-azino-bis(3ethylbenzothiazoline-6-sulfonic acid) (ABTS) scavenger (470.96 mg trolox equivalent (TE)/g and $394.96 \mathrm{mg} \mathrm{TE} / \mathrm{g}$ ) respectively (123).

Zeouk et al., (2020) evaluated in vivo antioxidant activities of ethanolic extracts of R.alaternus leaves using scavenging activities (DPPH assay) with butylated hydroxytoluene (BHT) as a standard. The crude extract showed activities with IC $_{50}$ value of $58 \mu \mathrm{g} / \mathrm{mL}$, which has good antioxidant activities when compared to $\mathrm{IC}_{50}$ value of $31 \mu \mathrm{g} / \mathrm{mL}$ exhibited by butylated hydroxytoluene (BHT), the positive control. Similarly, ethanolic extracts of $R$.alaternus leaves fraction have exhibited highest antioxidant activity with $\mathrm{IC}_{50}$ values of $32.76 \%$, $27.01 \%$ and $38.87 \%$, respectively(96).

Ammar et al., (2008) evaluated the antioxidant activity of aqueous extract and ethyl acetate fraction leaves of R.alaternus using Xanthine Oxidase (XOD) assay with allopurinol as positive control. The aqueous extract and ethyl acetate fraction exhibited high xanthine oxidase inhibiting with respective $\mathrm{IC}_{50}$ values of 208 and $137 \mu \mathrm{g} / \mathrm{mL}$ and super oxide anion scavenging effects with $\mathrm{IC}_{50}$ values of 132 and $117 \mu \mathrm{g} / \mathrm{mL}$ (124). Ammar et al., (2009) evaluated the antioxidant activities of methanolic and total oligomer flavonoid enriched extracts from R.alaternus leaves using DPPH radical scavenging and xanthine oxidase (XOD) assay with vitamin $\mathrm{E}$ and allopurinol as positive control, respectively. Rhamnetin-3-O- 
isorhamninoside (37) showed DPPH activities with IC $_{50}$ value of $1.5 \mu \mathrm{g} / \mathrm{mL}$ which is more antioxidant activity as compared to $\mathrm{IC}_{50}$ value of $3 \mu \mathrm{g} / \mathrm{mL}$ exhibited by vitamin $\mathrm{E}$ the standard drug. Similarly, the isolated compound exhibited xanthine oxidase (XOD) inhibiting with respective $\mathrm{IC}_{50}$ values of 18,81 and $40 \mu \mathrm{g} / \mathrm{mL}$ and superoxide anion scavenging effects with $\mathrm{IC}_{50}$ values of 42,79 and $35 \mu \mathrm{g} / \mathrm{mL}$ as compared with the positive control allopurinol having $\mathrm{IC}_{50}$ value of 37 and 4 $\mu \mathrm{g} / \mathrm{mL}$, respectively (72).

Ben Ammar et al., (2008) evaluated antioxidant activities of methanol extracts from R.alaternus leaves and root bark using DPPH radical scavenging and xanthine oxidase (XOD) assay with a-tocopherol and allopurinol as positive control, respectively. The root bark extract of R.alaternus revealed more effective than the leaves extract with $\mathrm{IC}_{50}$ values of 7.21 and $18.84 \mu \mathrm{g} / \mathrm{mL}$, respectively, compared to $\mathrm{IC}_{50}$ value of $3 \mu \mathrm{g} / \mathrm{mL}$ exhibited by a-tocopherol. Similarly, the leaves and root bark extract exhibited xanthine oxidase (XOD) inhibiting with respective $\mathrm{IC}_{50}$ values of 103.96 and $83.33 \mu \mathrm{g} / \mathrm{mL}$ and superoxide anion scavenging effects with $\mathrm{IC}_{50}$ values of 171 and 92 $\mu \mathrm{g} / \mathrm{mL}$ compared to allopurinol having IC $_{50}$ value of 37.3 and $6 \mu \mathrm{g} / \mathrm{mL}$, respectively(125).

Bhouri et al., (2012) evaluated antioxidant activities of Kaempferol-3-O- $\beta$-isorhamninoside and rhamnocitrin 3-O- $\beta$-isorhamninoside (37) isolated from leaves of $R$. alaternus using cupric reducing antioxidant capacity (CUPRAC), reducing power assay, and ferric reducing antioxidant power (FRAP) with Trolox $(10-1000 \mu \mathrm{g} / \mathrm{mL})$ as a positive control. The compound $\mathrm{K} 3 \mathrm{O}-\mathrm{ir}$ and $\mathrm{R} 3 \mathrm{O}-\mathrm{ir}$ exhibited a significant ability to reduce the $\mathrm{Cu}^{2+}$ neocuproine complex to $\mathrm{Cu}^{+}$neocuproine in a dose dependent manner. The highest values obtained with $1 \mathrm{mg} / \mathrm{mL}$ of each compound, were $374 \mu \mathrm{g} / \mathrm{mL}$ and $310 \mu \mathrm{g} / \mathrm{mL}$ equivalent to Trolox, respectively. The reducing power assay evaluates antioxidant capacity of compounds based on their ability to reduce ferric $\left(\mathrm{Fe}^{3+}\right)$ to ferrous $\left(\mathrm{Fe}^{2+}\right)$ ion through the donation of an electron, with the resulting ferrous ion $\left(\mathrm{Fe}^{2+}\right)$ formation monitored spectrophotometrically at $700 \mathrm{~nm}$. The tested compounds exhibited good reducing potential a concentration of $1 \mathrm{mg} / \mathrm{mL}$. R3O-ir exhibited higher reducing power of iron $(368 \mu \mathrm{g} / \mathrm{mL}$ equivalent of Trolox) than $\mathrm{K} 30$-ir $(330 \mu \mathrm{g} / \mathrm{mL}$ equivalent of Trolox) (126).

Chaouche et al., (2020) evaluated the antioxidant activities of methanol-acetone leaves and stem bark extracts of $R$. alaternus using DPPH radical scavenging and ferric reducing antioxidant potential (FRAP) assay with butylated hydroxyanisole (BHA) as a positive control. The leaves and stem bark extracts exhibited DPPH activities with $\mathrm{IC}_{50}$ values of 10.5 and $51.2 \mu \mathrm{g} / \mathrm{mL}$, respectively, which was weak activity compared to $\mathrm{IC}_{50}$ value of $5.6 \mu \mathrm{g} / \mathrm{mL}$ exhibited by BHA the positive control. Similarly, the leaves and stem bark extracts exhibited FRAP activities with EC $_{50}$ values of 0.4 and $1.8 \mu \mathrm{g} / \mathrm{mL}$, respectively, which was weak activity compared to $\mathrm{EC}_{50}$ value of 0.1 $\mu \mathrm{g} / \mathrm{mL}$ exhibited by BHA (127).

Hsiao et al., (1996) evaluated antioxidant activities of compound isotorachrysone (55) isolated from root bark extracts of R.nakaharai using ironinduced lipid peroxidation technique in rat brain homogenates with butylated hydroxytoluene $(\mathrm{BHT})$, alpha tocopherol and desferrioxamine as a positive controls. The study revealed that isotorachrysone (55) exhibited IC $_{50}$ value of 1.64 $\mu \mathrm{M}$, which was comparable to $\mathrm{IC}_{50}$ value of $1.08 \mu \mathrm{M}$ exhibited by BHT and was more potent than alpha tocopherol and desferrioxamine with $\mathrm{IC}_{50}$ values of 3.71 and $97.10 \mu \mathrm{M}$ as standard drug (111).

Kosalec et al., (2013) evaluated antioxidant activities of bark extracts of $R$. alaternus, $R$. fallax, $R$. intermedia and $R$. pumila using $\beta$-carotenelinoleic acid, DPPH radical scavenging, reducing power assay, and chelating activity with BHA, ascorbic acid, quercetin, and EDTA as positive controls. All the plant extracts, $R$. alaternus, $R$. fallax, $R$. intermedia and $R$. pumila exhibited activities using $\beta$-carotene-linoleic acid assay with $E_{50}$ values of $250,289,38$ and $29.5 \mu \mathrm{g} / \mathrm{mL}$ respectively, which was greater activity compared to $\mathrm{EC}_{50}$ value of $852 \mu \mathrm{g} / \mathrm{mL}$ exhibited by ascorbic acid. Similarly, all the plant extracts, $R$. alaternus, $R$. fallax, $R$. intermedia and $R$. pumila exhibited activities using reducing power assay with $\mathrm{EC}_{50}$ values of $0.91,1.99,0.81$ and $0.99 \mu \mathrm{g} / \mathrm{mL}$ respectively, which was comparable and greater activities compared to $\mathrm{EC}_{50}$ values of $7.53,1.8$ and $7.59 \mu \mathrm{g} / \mathrm{mL}$, respectively, exhibited by BHA, quercetin and ascorbic acid as standard drugs (86).

Lu et al., (2016) evaluated antioxidant activates of alaternin (10) and emodin-8-O-glucoside (20) isolated from methanol extracts of R.nakaharai heart wood using ABTS, DPPH and Superoxide dismutase (SOD-like) assay with ascorbic acid, 3-tbutyl-4-hydroxynisode (BHA) as positive control. The compound alaternin (10), showed DPPH activity with $\mathrm{IC}_{50}$ value of $117.7 \mu \mathrm{M}$, which was moderate activities compared to IC $_{50}$ value of 63.7 $\mu \mathrm{M}$ exhibited by ascorbic acid. Also, alaternin (10) and emodin-8-O-glucoside (20) exhibited SOD-like activities with $\mathrm{IC}_{50}$ values of 247 and $232 \mu \mathrm{M}$, respectively, which were better activities compared to $\mathrm{IC}_{50}$ value of $292 \mu \mathrm{M}$ exhibited by BHA (70). Chen et al., (2020) evaluated antioxidant activities of $60 \%$ ethanol stem and stem bark crude and semi purified extracts of R.prinoides using DPPH 
and ABTS assay with butylated hydroxytoluene (BHT) as positive control. The semi-purified extract exhibit DPPH activities with $\mathrm{IC}_{50}$ value of 0.2 $\mathrm{mg} / \mathrm{mL}$, which was more potent than the standard BHT having IC $_{50}$ value of $0.286 \mathrm{mg} / \mathrm{mL}$. Similarly, the crude extracts exhibit ABTS activities with $\mathrm{IC}_{50}$ value of $0.0596 \mathrm{mg} / \mathrm{mL}$, which was comparable to $\mathrm{IC}_{50}$ value of $\mathrm{BHT}(116)$.

Mazhar et al., (2013) evaluated antioxidant activities of methanol extract and their fractions (ethyl acetate, n-butanol, chloroform and nhexane) of R.triquetra aerial parts using DPPH assay with butylated hydroxytoluene (BHT) as a positive control. The crude extract and their fractions exhibited activities with $\mathrm{IC}_{50}$ values of 70.26, 7.59, 37.98, 60.09 and $182.99 \mu \mathrm{g} / \mathrm{mL}$ respectively, of which the ethyl acetate fraction showed better activity among the extracts, compared to $\mathrm{IC}_{50}$ value of $12.1 \mu \mathrm{g} / \mathrm{mL}$ exhibited by BHT (128). Boussahel et al., (2013) evaluated antioxidant activities of methanol and aqueous extract of $R$. alaternus leaves using DPPH and $\beta$ carotene-linoleic acid assay with butylated hydroxytoluene (BHT) as a positive control. The methanolic and aqueous extracts exhibited DPPH activities with $\mathrm{IC}_{50}$ values of 0.082 and 0.398 $\mathrm{mg} / \mathrm{mL}$, respectively, of which methanol extract is more active, compared to $\mathrm{IC}_{50}$ value of 0.032 $\mathrm{mg} / \mathrm{mL}$ exhibited by BHT. Similarly, the methanol extract exhibited activities using $\beta$-carotenelinoleic acid assay with $89 \%$ inhibition, which was comparable to $99.2 \%$ inhibition displayed by BHT (129). Boussahel et al., (2015) evaluated antioxidant activities of methanol bark extract of $R$. alaternus using oxygen radical absorbance capacity assay (ORAC) with trolox equivalent antioxidant capacity as a standard. The extract exhibited with $6.55 \mathrm{mmol} \mathrm{TE} / \mathrm{g}$ extract, which was more active as compared to the standard TEAC with $0.75 \mathrm{mmol} \mathrm{TE} / \mathrm{g}$ extract (130).

\section{Antiproliferative Activity}

Ben Ammar et al., (2008) evaluated the antiproliferative effect of root bark and leaves extracts obtained from $R$. alaternus against $\mathrm{K} 562$ human cell line and L1210 mouse lymphoma cells, at various concentrations comprised between 100 and $800 \mu \mathrm{g} / \mathrm{mL}$ using tetrazolium salt (3-(4,5dimethylthiazol-2-yl)-2,5-diphenyltetrazolium bromide) (MTT) assay. The leaves and roots extracts from $R$. alaternus showed interesting antiproliferative in a dose-dependent manner. The root extract was more effective than the leaves, on both types of leukemia cells. Indeed, concerning the $\mathrm{K} 562$ human cell, the $\mathrm{IC}_{50}$ values of roots and leaves extracts were determined at 165 and $260.69 \mu \mathrm{g} / \mathrm{mL}$, respectively. Concerning the $\mathrm{L} 1210$ cells, the $\mathrm{IC}_{50}$ values of roots and leaves extracts were determined at 210.73 and $343.10 \mu \mathrm{g} / \mathrm{mL}$, respectively, in the presence of a-tocopherol as positive control (125).

Chen et al., (2016) evaluated the antiproliferative effect of $80 \%$ methanol extracts obtained from R.davurica using protein-staining sulforhodamine $B$ (SRB) microculture colorimetric assay against human cancer cell lines of HT-29 (intestinal carcinoma) and SGC-7901 (gastric carcinoma). The extract exhibited significant dose-dependent antiproliferative activities against HT-29 and SGC7901 cells with IC $_{50}$ values of 24.96 and 89.53 $\mu \mathrm{g} / \mathrm{mL}$, respectively. Meanwhile, inhibitory activities against both HT-29 and SGC-7901 cells significantly increased by the treatment with $R$. davurica bark extract in a time-dependent manner from 24-96 $\mathrm{h}$ at a dose of $150 \mu \mathrm{g} / \mathrm{mL}$, although there was a decrease on SGC-7901 cells at the time from $72 \mathrm{~h}-96 \mathrm{~h}$ (84).

Chen et al., (2018) evaluated the antiproliferative effect of compounds apigenin (40) and kaempferol (33) obtained from $80 \%$ methanol extracts of R.davurica bark using MTT colorimetric assay against three human cancer cell lines of Hep G2 (hepatic cancer), SGC-7901 (gastric carcinoma), and HT-29 (intestinal carcinoma). Kaempferol (33) exhibited antiproliferative activities against HT-29, SGC-7901 and Hep G2 cells with IC $_{50}$ values of $25.7,13.43$ and $20 \mu \mathrm{g} / \mathrm{mL}$ respectively, while the compound apigenin (40) exhibited with $\mathrm{IC}_{50}$ values $19.79,17.76$ and $10.20 \mu \mathrm{g} / \mathrm{mL}$, respectively (74).

\section{Wound healing Activity}

Tessema et al., (2021) evaluated wound healing activities of methanol leaf extracts of R.prinoides using excision and incision models in adult Swiss albino mice, with nitrofurazone ointment as a standard. Treatment with $5 \%$ and $10 \%$ (w/w) methanol extract ointment exhibited significant wound recovery activities in both excision and incision models, which has higher activity when compared the standard nitrofurazone ointment (131).

\section{Cytotoxicity and Toxicity Activity}

Ahmadi et al., (2016) evaluated the cytotoxic activities of hydroalcoholic extracts of R.frangula against breast cancer cellline (MCF-7) using 3(4,5-dimethylthiazol-2-yl)-2,5-diphenyl tetrazolium bromide (MTT) assay. The extract exhibited activities with half maximal cytotoxic concentration $\left(\mathrm{CC}_{50}\right)$ value of $10 \mathrm{mg} / \mathrm{mL}$ (132). Ben Ammar et al., (2008) evaluated the cytotoxic activities of petroleum ether, chloroform, ethyl acetate, methanol and total oligomers flavonoids (TOF) enriched leaves extracts of $R$.alaternus against human chronic myelogenous $\mathrm{K} 562$ and murine Leukaemia L1210 cells using 3-(4,5dimethylthiazol-2-yl)-2,5-diphenyltetrazolium bromide (MTT) assay. The TOF extract exhibited 
with IC $_{50}$ values of $75 \mu \mathrm{g} / \mathrm{mL}$ and $198 \mu \mathrm{g} / \mathrm{mL}$ against $\mathrm{K} 562$ and $\mathrm{L} 1210$ cells, respectively. Similarly, the ethyl acetate extract showed activities with $\mathrm{IC}_{50}$ values of $232 \mu \mathrm{g} / \mathrm{mL}$ and 176 $\mu \mathrm{g} / \mathrm{mL}$ respectively (125).

Bhouri et al., (2011) evaluated the cytotoxic activities of kaempferol 3-O- $\beta$-isorhamninoside and rhamnocitrin $3-0-\beta$-isorhamninoside isolated from methanol leaves extracts of R.alaternus using Alamar blue assay against human lymphoblastoid TK6 cells, with cells treated by $0.5 \%$ DMSO as a control. The compound neither K3O-ir nor R3O-ir reached $50 \%$ inhibition of TK6 cell proliferation (75). Chen et al., (2016) evaluated in vitro toxicity activity of $80 \%$ ethanol bark extracts of $R$. davurica against normal human hepatic cells ( $L-$ O2) using protein-staining sulforhodamine B (SRB) microculture colorimetric assay. The extract exhibited activities with $\mathrm{IC}_{50}$ value of 229.19 $\mu \mathrm{g} / \mathrm{mL}$ on $\mathrm{L}-\mathrm{O} 2$, which suggested that $R$. davurica bark extract showed very low or no toxicity on hepatic cell viability (84).

Mai et al., (2001) evaluated cytotoxicity activity of prinoidin (23) isolated from methanol extracts of R.nepalensis fruit against KB (human epidermoid carcinoma of the mouth) cell using MTT assay with doxorubicin as a positive control. Prinoidin (23) exhibited $\mathrm{IC}_{50}$ value of $0.045 \mu \mathrm{M}$, which was four times more potent than the standard, doxorubicin, having $\mathrm{IC}_{50}$ value of $0.2 \mu \mathrm{M}(69)$. Boussahel et al. (2015) evaluated cytotoxicity of methanol extract of R.alaternus bark against human monocytic leukemia cells (U937) using trypan blue assay with taxol as standard drug. The extract exhibited activities with $\mathrm{IC}_{50}$ values of $6.39 \mu \mathrm{g} / \mathrm{mL}$, which was comparable to IC $_{50}$ value of $2.47 \mu \mathrm{g} / \mathrm{mL}$ exhibited by taxol the standard drug (130).

\section{Anti-tyrosinase Activity}

Lu et al., (2016) evaluated the anti-tyrosinase activity of 6-methoxysorigenin (12) isolated from methanol extracts of R.nakaharai using mushroom tyrosine inhibitory assay with kojic acid as positive control. The study revealed that 6methoxysorigenin (12) exhibited activities with $\mathrm{IC}_{50}$ value of $42.2 \mu \mathrm{M}$, which was twofold inhibitory effect than the positive control kojil acid having $\mathrm{IC}_{50}$ value of $82.1 \mu \mathrm{M}(70)$.

\section{Antihyperlipidemic Activity}

Tacherfiout et al., (2018) evaluated antihyperlipidemic activities of methanol extracts of R.alaternus leaf on circulating lipids in rats with Triton WR-1339-induced hyperlipidemia, intracellular lipid accumulation and expression of genes of fatty acid metabolism in human hepatoma HepG2 cells, and adipogenesis in the 3T3-L1 murine adipocyte cell model. The Oral crude extract administration decreased blood levels of cholesterol and triacylglycerol in hyperlipidemic rats (by $60 \%$ and $70 \%$, respectively, at $200 \mathrm{mg}$ extract $/ \mathrm{kg})$. In HepG2 cells, the extract exposure dose-dependently decreased intracellular lipids and up-regulated gene expression of carnitine palmitoyl transferase 1 involved in fatty acid oxidation, while in the 3T3-L1 model the extract favored preadipocyte proliferation and adipogenesis, pointing to positive effects on adipose tissue expandability(133).

Ammar et al., (2009) evaluated the anti lipid peroxidation activity of kaempferol 3-O- $\beta$ isorhamninoside, rhamnocitrin-3-Oisorhamninoside and rhamnetin-3-O- $\beta$ isorhamninoside (37) from methanol leaf extracts of $R$. alaternuswas estimated by calculating the values of malondialdehyde (MDA) in cultured K562 human chronic myelogenous leukemia cells. In this study, the compounds displayed $\mathrm{IC}_{50}$ values of 180,320 and $106 \mu \mathrm{g} / \mathrm{mL}$, respectively, compared to IC $_{50}$ value of $15 \mu \mathrm{g} / \mathrm{mL}$ exhibited by vitamin $\mathrm{C}$ as a reference (72).

\section{Antimutagenic activity}

Ammar et al., (2008) evaluated the antimutagenic activity of leaves extracts by the Ames assay, using the mutagen Aflatoxin B1 (AFB1) at a concentration of $10 \mu \mathrm{g} / \mathrm{mL}$. The experiment was carried out with two strains of Salmonella Typhimurium (i.e., TA98 and TA100) in the presence of various extracts, and spontaneous revertant was used as control. Petroleum ether, chloroform, methanol, water, and total oligomers flavonoids (TOF) extracts obtained by $R$. alaternus were investigated at various doses $(10,50$, and $250 \mu \mathrm{g} / \mathrm{mL}$ ) and remarkably reduced the AFB1induced mutagenicity. The study revealed that ethyl acetate extract to be the most effective at a dose of $250 \mu \mathrm{g} / \mathrm{mL}$. At such dose, the inhibition percentage of mutagenicity was determined by the Ames assay up to $78 \%$ for the TA98 strain (124).

\section{Antigenotoxic activity}

Bhouriet al., (2011) evaluated the antigenotoxic activity of Kaempferol 3-O- $\beta$-isorhamninoside and rhamnocitrin3-O- $\beta$-isorhamninoside isolated from methanol extract of leaves of $R$. alaternus on $E$. coli PQ37 using SOS chromo test with two positive control snifuroxazide and aflatoxin B1 used at 10 $\mu \mathrm{g} /$ assay and $5 \mu \mathrm{g}$ /assay, respectively. The assay carried out in absence of both aflatoxin B1 and extracts constituted the negative control. For the three flavonoid concentrations studied (1, 5, and $10 \mu \mathrm{g} /$ assay), the antigenotoxic activity of rhamnocitrin $3-0-\beta$-isorhamninoside was higher than the one determined for Kaempferol 3-O- $\beta$ isorhamninoside (73).

Bhouri et al., (2012) evaluated antigenotoxic properties of Kaempferol $3-0-\beta$-isorhamninoside 
(31) and rhamnocitrin 3-O- $\beta$-isorhamninoside (36) isolated from leaves of $R$. alaternus (i.e.,) using comet assay on human lymphoblastoid cells TK6 and NH32. Quantification of the comet data was reported as Total DNA damage (TDD). The compound exhibited no significant difference was detected between the TDD induced by $\mathrm{K} 3 \mathrm{O}$-ir (TDD $=212,151$ and 67 at concentrations of respectively of 800,400 and $200 \mu \mathrm{g} / \mathrm{mL}$ ) and that induced by R30-ir (TDD=238, 139 and 110) at the same tested concentrations in TK6 cells and the negative control (non-treated cells; TDD $=163$ ) on the other hand. In the opposite, a significant increase of the total DNA damage $(T D D=348)$ was observed in TK6 cells exposed to $75 \mu \mathrm{M}$ of $\mathrm{H}_{2} \mathrm{O}_{2}$, compared to the untreated cells. Likewise, $\mathrm{K} 3 \mathrm{O}-\mathrm{ir}$ and $\mathrm{R} 30$-ir revealed a non genotoxic effect at the doses of (200 and $400 \mu \mathrm{g} / \mathrm{ml}$ ) whereas the highest tested concentration $(800 \mu \mathrm{g} / \mathrm{mL})$ exhibited a genotoxic effect when tested with $\mathrm{NH} 32$ cells. The TDD values were 240 and 226 with respectively $\mathrm{K} 30$-ir and R3O-ir, suggesting inducing of DNA breakage in p53 deficient lymphoblastoid human cells (126).

Summary of pharmacological activity of Rhamanus species is presented in Table 3 below. 
Table 3: Pharmacological activities of extracts and isolated compounds from Rhamnus species

\begin{tabular}{|c|c|c|c|c|c|c|}
\hline Activity & Plant species & Extract & Plant Part & Method & Effect & Refs \\
\hline Hepatoprotective & R. alaternus & aqueous & leaves & $\begin{array}{l}\text { Biochemical and } \\
\text { histopathological } \\
\text { changes in Wistar } \\
\text { rats }\end{array}$ & $\begin{array}{l}\text { Extract reduced levels of alkaline phosphatase (ALP), } \\
\text { Glutamic oxaloacetic transaminase (GOT), Glutamic } \\
\text { pyruvic transaminase (GPT) and total bilirubin and } \\
\text { significantly attenuated deleterious histopathological } \\
\text { changes in the liver }\end{array}$ & $(14)$ \\
\hline Anti-inflammatory & R. alaternus & ethanol & Stem bark & $\begin{array}{l}\text { Carrageenan- } \\
\text { induced rat paw } \\
\text { edema assay }\end{array}$ & $\begin{array}{l}\text { extract exhibited anti-inflammatory activity with inhibition } \\
\text { of } 54.50 \% \text { and } 54.77 \% \text { after } 3 \mathrm{hr} \text { and } 4 \mathrm{hr} \text { of treatment } \\
\text { as compared the standard drug indomethacin ( } 10 \mathrm{mg} / \mathrm{kg}) \\
\text { showed the inhibition of } 50.46 \% \text {, and } 51.78 \% \text { after } 3 \mathrm{hr} \\
\text { and } 4 \mathrm{hr} \text { of treatment, respectively }\end{array}$ & (115) \\
\hline Anti-inflammatory & R. prinoides & ethanol & $\begin{array}{l}\text { Stem and stem } \\
\text { bark }\end{array}$ & $\begin{array}{r}\text { Cyclooxygenase } \\
(\text { COX-2) assay }\end{array}$ & $\begin{array}{l}\text { extract exhibited activities with } \mathrm{IC}_{50} \text { value of } 20.6 \mu \mathrm{g} / \mathrm{mL} \text {, } \\
\text { which was weak activities compared to } \mathrm{IC}_{50} \text { value of } 6.33 \\
\mu \mathrm{g} / \mathrm{mL} \text { exhibited by ascorbic acid the standard }\end{array}$ & $(116)$ \\
\hline Anti-inflammatory & R. davurica & methanol & bark & $\begin{array}{r}\text { Cyclooxygenase } \\
(\text { COX-2) assay }\end{array}$ & $\begin{array}{l}\text { The isolated compounds, apigenin (40) and Kaempferol } \\
\text { (33) exhibited activities with } \mathrm{IC}_{50} \text { values of } 10.14 \text { and } \\
9.27 \mu \mathrm{g} / \mathrm{mL} \text { respectively }\end{array}$ & (74) \\
\hline Antibacterial & R. prinoides & $\begin{array}{l}\text { Methanol } \\
\text { and } \\
\text { chlorofor } \\
\mathrm{m}\end{array}$ & leaves & Agar well diffusion & $\begin{array}{l}\text { Extract exhibited activities against } S \text {. aureus, S. pyogen, } \\
\text { S. pneumoniae, and S. typhi with MIC value of methanol } \\
\text { and chloroform fractions ranged from } 8.13 \mathrm{mg} / \mathrm{mL} \text { to } 32.5 \\
\mathrm{mg} / \mathrm{mL} \text { and from } 8.13 \mathrm{mg} / \mathrm{mL} \text { to } 16.25 \mathrm{mg} / \mathrm{mL} \text {, } \\
\text { respectively. }\end{array}$ & (117) \\
\hline Antibacterial & R. californica & methanol & Leaf and bark & Disc diffusion & $\begin{array}{l}\text { Both extracts exhibited activities against } B \text {. cereus, } S \text {. } \\
\text { pyogenes, M. smegmatis, } S \text {. aureus, methicillin-resistant } \\
\text { S. aureus (MRSA) with MIC value of } 3.3-6.0 \mathrm{mg} / \mathrm{mL}\end{array}$ & (77) \\
\hline Antibacterial & R. alaterus & $\begin{array}{l}\text { Ethyl } \\
\text { acetate } \\
\text { and Total } \\
\text { Oligomers } \\
\text { flavonoids } \\
\text { (TOF) }\end{array}$ & leaves & $\begin{array}{l}\text { Microdilution and } \\
\text { agar dilution }\end{array}$ & $\begin{array}{l}\text { The TOF extract exhibited activities against S. aureus, } E \text {. } \\
\text { faecalis, } E \text {. coli, S. enteritidis and S. typhimurium with } \\
\mathrm{MIC} \text { values of } 120 \mu \mathrm{g} / \mathrm{mL}, 175 \mu \mathrm{g} / \mathrm{mL}, 1.75 \mathrm{mg} / \mathrm{mL}, 125 \\
\mu \mathrm{g} / \mathrm{mL} \text { and } 62.5 \mu \mathrm{g} / \mathrm{mL} \text { respectively, while the ethyl } \\
\text { acetate extract exhibited with } \mathrm{MIC} \text { values of } 70 \mu \mathrm{g} / \mathrm{mL} \text {, } \\
150 \mu \mathrm{g} / \mathrm{mL}, 3.75 \mathrm{mg} / \mathrm{mL}, 100 \mu \mathrm{g} / \mathrm{mL} \text { and } 175 \mu \mathrm{g} / \mathrm{mL} \\
\text { respectively }\end{array}$ & $(118)$ \\
\hline Antibacterial & R. wightii & $\begin{array}{l}\text { Ethyl } \\
\text { acetate }\end{array}$ & Whole part & Agar disc diffusion & $\begin{array}{l}\text { Extract exhibited activities against } S \text {. aureus, } B \text {. cereus, } \\
E \text {. faecalis, K.pneumonia, } P \text {. aeruginosa and } E \text {. coliwith } \\
\text { inhibition zones (in mm) of } 15,16.66,15,19,10.66 \text { and } \\
12 \text { respectively }\end{array}$ & $(76)$ \\
\hline Antibacterial & $R$. & methanol & Bark & Micro-dilution & All extract exhibited activities against $S$. aureus, $P$. & $(86)$ \\
\hline
\end{tabular}




\begin{tabular}{|c|c|c|c|c|c|c|}
\hline & $\begin{array}{l}\text { alaternus, } R \text {. } \\
\text { fallax, } R . \\
\text { intermedia } \\
\text { and } \\
\text { R. pumila }\end{array}$ & & & broth assay & $\begin{array}{l}\text { aeruginosa and } E \text {. coli with MIC value of ranging from } \\
1.25 \text { to } 2.5 \mu \mathrm{g} / \mathrm{mL}\end{array}$ & \\
\hline Antibacterial & R. califormica & methanol & Leaves & $\begin{array}{l}\text { Kirby-Bauer disc } \\
\text { diffusion }\end{array}$ & $\begin{array}{l}\text { Extract exhibited activities against Staphylococcus aureus, } \\
\text { Methicillin-resistant Staphylococcusaureus, Bacillus } \\
\text { cereus,Pseudomonas aeruginosa,Streptococcus pyogenes } \\
\text { and Escherichia coliwith zone of inhibition ranging from } 9 \\
\mathrm{~mm} \text { to } 14.3 \mathrm{~mm}\end{array}$ & (77) \\
\hline Antibacterial & R. wightii & $\begin{array}{l}\text { Ethyl } \\
\text { acetate }\end{array}$ & Whole part & Agar disc diffusion & $\begin{array}{l}\text { Musizen (54) exhibited activities against S. aureus and } K \text {. } \\
\text { pneumonia with MIC value of } 9 \mu \mathrm{g} / \mathrm{mL} \text {, which was more } \\
\text { potent than the standard drug Streptomycin having MIC } \\
\text { value of } 120 \mu \mathrm{g} / \mathrm{mL}\end{array}$ & $(76)$ \\
\hline Antifungal & $\begin{array}{l}\text { R. alaternus, } \\
\text { R. fallax, } R . \\
\text { intermedia } \\
\text { and } \\
\text { R. pumila }\end{array}$ & methanol & Bark & $\begin{array}{l}\text { micro-dilution } \\
\text { broth assay }\end{array}$ & $\begin{array}{l}\text { All extract exhibited activities against } C \text {. albicans, } A \text {. niger } \\
\text { and M.gypseum with MIC values of } 0.625 \mathrm{mg} / \mathrm{mL} \text { and } 2.5 \\
\mathrm{mg} / \mathrm{mL} \text { against } C \text {. albicans and A.niger respectively, while } \\
\text { the plant extracts } R \text {. fallax,R. intermedia and } R \text {. pumila } \\
\text { exhibited with MIC value of } 0.313 \mathrm{mg} / \mathrm{ml} \text { against } \\
\text { dermatophyte species (M. gypseum) }\end{array}$ & $(86)$ \\
\hline Antimalarial & $R$. prinoides & $\begin{array}{l}\text { Chlorofor } \\
\mathrm{m}\end{array}$ & Root bark & ELISA assay & $\begin{array}{l}\text { extract exhibited activities against chloroquine-sensitive } \\
\text { Plasmodium falciparum strain with } \mathrm{IC}_{50} \text { value of } 3.53 \\
\mu \mathrm{g} / \mathrm{mL} \text {, which was weak activities compared to } \mathrm{IC}_{50} \text { value } \\
\text { of } 0.004 \mu \mathrm{g} / \mathrm{mL} \text { exhibited by chloroquine the standard } \\
\text { drug }\end{array}$ & (119) \\
\hline Antimalarial & R. prinoides & $\begin{array}{l}\text { Hexane\& } \\
\text { dichlorom } \\
\text { ethane }\end{array}$ & root & Radioisotope & $\begin{array}{l}\text { extracts of hexane and dichloromethane exhibited } \\
\text { activities anti-plasmodia with } \mathrm{IC}_{50} \text { values of } 19.9 \mu \mathrm{g} / \mathrm{mL} \\
\text { and } 30.3 \mu \mathrm{g} / \mathrm{mL} \text {, respectively }\end{array}$ & $(120)$ \\
\hline Antimalarial & $\begin{array}{l}R . \text { prinoides } \\
\text { and } R . \text { staddo }\end{array}$ & aqueous & $\begin{array}{l}\text { Leaves and root } \\
\text { bark }\end{array}$ & $\begin{array}{l}\text { blood-induced CQ- } \\
\text { resistant rodent } \\
\text { parasite in mice }\end{array}$ & $\begin{array}{l}\text { The plant extract and standard drug,chloroquine (CQ) } \\
\text { potential effects against a blood-induced CQ-resistant } \\
\text { rodent parasite in mice showed high chemo suppression } \\
\text { in the range } 51 \%-75 \%\end{array}$ & $(122)$ \\
\hline Antioxidant & R. alaterus & methanol & $\begin{array}{l}\text { Root bark and } \\
\text { leaves }\end{array}$ & $\begin{array}{l}\text { DPPH, Xanthine } \\
\text { Oxidase (XOD) } \\
\text { and } \\
\text { Superoxide anion } \\
\text { scavenging effects }\end{array}$ & $\begin{array}{l}\text { The root bark and Leaves extract exhibited } \mathrm{DPPH} \\
\text { activities with IC } 50 \text { values of } 7.21 \text { and } 18.84 \mu \mathrm{g} / \mathrm{mL} \text {, } \\
\text { respectively, when compared to IC } \mathrm{C}_{50} \text { value of } 3 \mu \mathrm{g} / \mathrm{mL} \\
\text { exhibited by a-tocopherol the positive control. Similarly, } \\
\text { the leaves and root bark extract exhibited xanthine } \\
\text { oxidase (XOD) inhibiting with respective IC } \mathrm{I}_{50} \text { values of } \\
103.96 \text { and } 83.33 \mu \mathrm{g} / \mathrm{mL} \text { and superoxide anion } \\
\text { scavenging effects with IC } \mathrm{C}_{50} \text { values of } 171 \text { and } 92 \mu \mathrm{g} / \mathrm{mL} \\
\text { as compared with the positive control allopurinol having }\end{array}$ & $(125)$ \\
\hline
\end{tabular}




\begin{tabular}{|c|c|c|c|c|c|c|}
\hline & & & & & IC50 value of 37.3 and $6 \mu \mathrm{g} / \mathrm{mL}$ respectively & \\
\hline Antioxidant & R. petiolaris & $\begin{array}{l}\text { Methanol } \\
\text { and } \\
\text { aqueous }\end{array}$ & fruit & $\begin{array}{l}\text { DPPH and ABTS } \\
\text { assay }\end{array}$ & $\begin{array}{l}\text { Extracts exhibited activities with } 470.96 \mathrm{mg} \text { trolox } \\
\text { equivalent (TE)/g and } 394.96 \mathrm{mg} \mathrm{TE} / \mathrm{g} \text { ) respectively }\end{array}$ & $(123)$ \\
\hline Antioxidant & R. alaternus & methanol & leaves & $\begin{array}{l}\text { DPPH, Xanthine } \\
\text { Oxidase and } \\
\text { Superoxide anion } \\
\text { scavenging effects }\end{array}$ & $\begin{array}{l}\text { Rhamnetin-3-O- } \beta \text {-isorhamninoside (38) exhibited DPPH } \\
\text { activities with } \mathrm{IC}_{50} \text { value of } 1.5 \mu \mathrm{g} / \mathrm{mL} \text { which is } \mathrm{more} \\
\text { antioxidant activity as compared to } \mathrm{IC}_{50} \text { value of } 3 \mu \mathrm{g} / \mathrm{mL} \\
\text { exhibited by vitamin } \mathrm{E} \text { the standard drug. Similarly, } \\
\text { kaempferol } 3-\mathrm{O}-\beta \text {-isorhamninoside }(\mathbf{3 1}) \text {, rhamnocitrin-3- } \\
\text { O- } \beta \text {-isorhamninoside }(\mathbf{3 6}) \text { and rhamnetin-3-O- } \\
\text { isorhamninoside (37) exhibited xanthine oxidase (XOD) } \\
\text { inhibiting with respective } \mathrm{IC}_{50} \text { values of } 18,81 \text { and } 40 \\
\mu \mathrm{g} / \mathrm{mL} \text { and superoxide anion scavenging effects with IC } 50 \\
\text { values of } 42,79 \text { and } 35 \mu \mathrm{g} / \mathrm{mL} \text { as compared with the } \\
\text { positive control allopurinol having } \mathrm{IC}_{50} \text { value of } 37 \text { and } \\
4 \mu \mathrm{g} / \mathrm{mL} \text { respectively }\end{array}$ & $(72)$ \\
\hline Antioxidant & $R$, alaternus & methanol & leaf & $\begin{array}{l}\text { Super oxide } \\
\text { radical scavenging }\end{array}$ & $\begin{array}{l}\text { Kaempferol 3-O- } \beta \text {-isorhamninoside (31) and rhamnocitrin } \\
3 \text {-O- } \beta \text {-isorhamninoside exhibited activities with } \mathrm{IC}_{50} \\
\text { values } 18.75 \text { and } 22.5 \mu \mathrm{g} / \mathrm{mL} \text { respectively }\end{array}$ & $(73)$ \\
\hline Antioxidant & R. nakaharai & methanol & Heart wood & DPPH assay & $\begin{array}{l}\text { The isolated compound, alaternin (10) exhibited activities } \\
\text { with IC } \mathrm{C}_{50} \text { value of } 117.7 \mu \mathrm{M} \text {, which was moderate } \\
\text { activities compared to } \mathrm{IC}_{50} \text { value of } 63.7 \mu \mathrm{M} \text { exhibited by } \\
\text { ascorbic acid the standard drug }\end{array}$ & $(70)$ \\
\hline Antioxidant & R. nakaharai & & Root bark & $\begin{array}{l}\text { Iron induced lipid } \\
\text { peroxidation }\end{array}$ & $\begin{array}{l}\text { The isolated compound, isotorachrysone (55) exhibited } \\
\text { activities with IC } \mathrm{C}_{50} \text { value of } 1.64 \mu \mathrm{M} \text {, which was } \\
\text { comparable to IC } 50 \text { value of } 1.08 \mu \mathrm{M} \text { exhibited by the } \\
\text { standard butylated hydroxyl toluene }(\mathrm{BHT}) \text { and was more } \\
\text { potent than a- tocophenol and desferrioxamine with } \mathrm{IC}_{50} \\
\text { values of } 3.71 \text { and } 97.10 \mu \mathrm{M} \text { respectively }\end{array}$ & $(111)$ \\
\hline Antioxidant & R. alaternus & ethanol & leaves & DPPH assay & $\begin{array}{l}\text { extract exhibited activities with } \mathrm{IC}_{50} \text { value of } 58 \mu \mathrm{g} / \mathrm{mL} \text {, } \\
\text { which has good antioxidant activities when compared to } \\
\mathrm{IC}_{50} \text { value of } 31 \mathrm{\mu g} / \mathrm{mL} \text { exhibited by } \\
\text { butylatedhydroxytoluene }(\mathrm{BHT}) \text {, the positive control }\end{array}$ & $(96)$ \\
\hline Antioxidant & R. alaterus & $\begin{array}{l}\text { Aqueous } \\
\text { and ethyl } \\
\text { acetate } \\
\text { fraction }\end{array}$ & leaves & $\begin{array}{l}\text { Xanthine Oxidase } \\
\text { (XOD) and Super } \\
\text { oxide anion } \\
\text { scavenging }\end{array}$ & $\begin{array}{l}\text { aqueous extract and ethyl acetate fraction exhibited high } \\
\text { xanthine oxidase inhibiting with respective } \mathrm{IC}_{50} \text { values of } \\
208 \text { and } 137 \mu \mathrm{g} / \mathrm{mL} \text {, and super oxide anion scavenging } \\
\text { effects with } \mathrm{IC}_{50} \text { values of } 132 \text { and } 117 \mu \mathrm{g} / \mathrm{mL}\end{array}$ & $(124)$ \\
\hline Antioxidant & R. alaterus & $\begin{array}{l}\text { Methanol- } \\
\text { acetone }\end{array}$ & $\begin{array}{l}\text { Leaf and stem } \\
\text { bark }\end{array}$ & $\begin{array}{l}\text { DPPH assay and } \\
\text { ferric reducing } \\
\text { antioxidant } \\
\text { potential }\end{array}$ & $\begin{array}{l}\text { leaves and stem bark extracts exhibited DPPH activities } \\
\text { with IC } \text { IC }_{50} \text { values of } 10.5 \text { and } 51.2 \mu \mathrm{g} / \mathrm{mL} \text { respectively, } \\
\text { which was weak activity compared to } \mathrm{IC}_{50} \text { value of } \\
5.6 \mu \mathrm{g} / \mathrm{mL} \text { exhibited by BHA the positive control and FRAP }\end{array}$ & $(127)$ \\
\hline
\end{tabular}


activities with $\mathrm{EC}_{50}$ values of 0.4 and $1.8 \mu \mathrm{g} / \mathrm{mL}$ respectively, which was weak activity compared to $\mathrm{EC}_{50}$

\begin{tabular}{|c|c|c|c|c|c|c|}
\hline Antioxidant & R. alaternus & & leaves & $\begin{array}{l}\text { Cupric reducing } \\
\text { antioxidant } \\
\text { (CUPRAC), } \\
\text { reducing power } \\
\text { assay and ferric } \\
\text { reducing } \\
\text { antioxidant power } \\
\text { (FRAP) }\end{array}$ & $\begin{array}{l}\text { Kaempferol 3-O- } \beta \text {-isorhamninoside (31) and rhamnocitrin } \\
3 \text {-O- } \beta \text {-isorhamninoside (36) exhibited CUPRAC and } \\
\text { reduced power assay activities with IC } 50 \text { value of } 1 \\
\mathrm{mg} / \mathrm{mL} \text {, while FRAP activities exhibited at the same } \\
\text { concentration } 1000 \mu \mathrm{g} / \mathrm{mL} \text { reduce a maximum of iron ion } \\
\text { by } 300 \mu \mathrm{g} / \mathrm{mL} \text { and } 320 \mu \mathrm{g} / \mathrm{mL} \text { equivalent of Trolox } \\
\text { respectively }\end{array}$ & (126) \\
\hline Antioxidant & $\begin{array}{l}\text { R. alaternus, } \\
R . \text { Fallax, } \\
R . \text { intermedia } \\
\text { and R. pumila }\end{array}$ & & Bark & $\begin{array}{l}\text { beta-Carotene- } \\
\text { linoleic acid, DPPH } \\
\text { radical } \\
\text { scavenging, } \\
\text { reducing power } \\
\text { assay and } \\
\text { Chelating activity }\end{array}$ & $\begin{array}{l}\text { All exhibited activities using } \beta \text {-Carotene-linoleic acid assay } \\
\text { with } \mathrm{EC}_{50} \text { values of } 250,289,38 \text { and } 29.5 \mu \mathrm{g} . \mathrm{mL} \\
\text { respectively, which was greater activity compared to } \mathrm{EC}_{50} \\
\text { value of } 852 \mu \mathrm{g} / \mathrm{mL} \text { exhibited by ascorbic acid the positive } \\
\text { control. Similarly, all the plant extracts exhibited activities } \\
\text { using reducing power assay with } \mathrm{EC}_{50} \text { values of } 0.91 \text {, } \\
1.99,0.81 \text { and } 0.99 \mu \mathrm{g} / \mathrm{mL} \text { respectively, which was } \\
\text { comparable and greater activities compared to EC } \mathrm{E}_{50} \\
\text { values of } 7.53,1.8 \text { and } 7.59 \mu \mathrm{g} / \mathrm{mL} \text { respectively exhibited } \\
\text { by } \mathrm{BHA} \text {, quercetin and ascorbic acid as standard drugs }\end{array}$ & $(86)$ \\
\hline Antioxidant & R. prinoides & ethanol & $\begin{array}{l}\text { Stem and stem } \\
\text { bark }\end{array}$ & $\begin{array}{l}\text { DPPH } \\
\text { and ABTS assay }\end{array}$ & $\begin{array}{l}\text { The semi purified extract exhibited DPPH activities with } \\
\text { IC } 50 \text { value of } 0.2 \mathrm{mg} / \mathrm{mL} \text {, which was more potent than the } \\
\text { standard BHT having IC } \mathrm{C}_{50} \text { value of } 0.286 \mathrm{mg} / \mathrm{mL} \text {. } \\
\text { Similarly, the crude extracts exhibit ABTS activities with } \\
\text { IC }_{50} \text { value of } 0.0596 \mathrm{mg} / \mathrm{mL} \text {, which was comparable to } \\
\text { IC }_{50} \text { value of BHT, the positive control }\end{array}$ & $(116)$ \\
\hline Antioxidant & R. triquetra & methanol & Aerial part & DPPH assay & $\begin{array}{l}\text { crude extract and their fractions (ethyl acetate, n- } \\
\text { butanol, chloroform and n-hexane) exhibited activities } \\
\text { with } \mathrm{IC}_{50} \text { values of } 70.26,7.59,37.98,60.09 \text { and } 182.99 \\
\mathrm{\mu g} / \mathrm{mL} \text { respectively, which was the ethyl acetate fraction, } \\
\text { is more active compared to } \mathrm{IC}_{50} \text { value of } 12.1 \mathrm{\mu g} / \mathrm{mL} \\
\text { exhibited by the standard (BHT) }\end{array}$ & (128) \\
\hline Antioxidant & R. alaternus & $\begin{array}{l}\text { Methanol } \\
\text { and } \\
\text { aqueous }\end{array}$ & leaves & $\begin{array}{l}\text { DPPH } \\
\text { and } \\
\beta \text {-carotene-linoleic } \\
\text { acid assay }\end{array}$ & $\begin{array}{l}\text { The methanol and aqueous extracts exhibited DPPH } \\
\text { activities with IC } \mathrm{IC}_{50} \text { values of } 0.082 \text { and } 0.398 \mathrm{mg} / \mathrm{mL} \\
\text { respectively, which was the methanol extract, is more } \\
\text { active compared to IC } \mathrm{I}_{50} \text { value of } 0.032 \mathrm{mg} / \mathrm{mL} \text { exhibited } \\
\text { by the standard (BHT). Similarly, the methanol extract } \\
\text { exhibit activities using } \beta \text {-carotene-linoleic acid assay with } \\
89 \% \text { inhibition, which was comparable to } 99.2 \% \text { inhibition } \\
\text { by BHT the standard }\end{array}$ & (129) \\
\hline
\end{tabular}




\begin{tabular}{|c|c|c|c|c|c|c|}
\hline Antioxidant & R. alaternus & methanol & leaves & $\begin{array}{l}\text { Oxygen radical } \\
\text { absorbance } \\
\text { capacity } \\
\text { (ORAC) }\end{array}$ & $\begin{array}{l}\text { extract exhibited with } 6.55 \mathrm{mmol} \mathrm{TE} / \mathrm{g} \text { extract, which was } \\
\text { more active as compared to the standard TEAC with } 0.75 \\
\mathrm{mmol} \mathrm{TE} / \mathrm{g} \text { extract }\end{array}$ & (130) \\
\hline Anti-hyperlipidemia & R. alaternus & methanol & leaves & $\begin{array}{l}\text { Calculating } \\
\text { Malondialdehyde } \\
\text { in cultured K562 } \\
\text { cells }\end{array}$ & $\begin{array}{l}\text { kaempferol 3-O- } \beta \text {-isorhamninoside (31), rhamnocitrin-3- } \\
\text { O- } \beta \text {-isorhamninoside (36) and rhamnetin-3-O- } \\
\text { isorhamninoside (37) from methanol leaf extracts } \\
\text { exhibited by calculating the values of malondialdehyde } \\
\text { (MDA) in cultured K562 human chronic myelogenous } \\
\text { leukemia cells with } \mathrm{IC}_{50} \text { values of isolated compound } \\
180,320 \text { and } 106 \mu \mathrm{g} / \mathrm{mL} \text {, respectively }\end{array}$ & $(72)$ \\
\hline Anti-hyperlipidemia & R. alaternus & methanol & leaves & $\begin{array}{l}\text { Using } \\
\text { Hyperlipidemia } \\
\text { rats }\end{array}$ & $\begin{array}{l}\text { The Oral crude extract administration decreased blood } \\
\text { levels of cholesterol and triacylglycerols in human } \\
\text { hepatoma HePG } 2 \text { and } 3 T 3-\mathrm{L} 1 \text { murine dipocyte cell } \\
\text { hyperlipidemic rats model (by } 60 \% \text { and } 70 \% \text {, } \\
\text { respectively, at } 200 \mathrm{mg} \text { extract/kg) }\end{array}$ & (133) \\
\hline Anti-proliferative & R. alaternus & methanol & $\begin{array}{l}\text { Root bark and } \\
\text { leaf }\end{array}$ & MTT assay & $\begin{array}{l}\text { The root barks and leaf extract exhibited activities against } \\
\mathrm{K} 562 \text { cells with } \mathrm{IC}_{50} \text { value of } 165 \text { and } 260.69 \mathrm{\mu g} / \mathrm{mL} \text {. } \\
\text { Similarly the extracts exhibited activities against } \mathrm{L} 1210 \\
\text { cells with IC } \mathrm{C}_{50} \text { value of } 210.73 \text { and } 343.10 \mathrm{\mu g} / \mathrm{mL} \text {, } \\
\text { respectively }\end{array}$ & (125) \\
\hline Anti-proliferative & R. davurica & methanol & bark & $\begin{array}{l}\text { sulforhodamine B } \\
\text { (SRB)micro } \\
\text { culture } \\
\text { colorimetric assay }\end{array}$ & $\begin{array}{l}\text { The extract exhibited activities against human cancer cell } \\
\text { lines } \mathrm{HT}-29 \text { and SGC-7901 with } \mathrm{IC}_{50} \text { values of } 24.96 \text { and } \\
89.53 \mu \mathrm{g} / \mathrm{mL} \text {. respectively }\end{array}$ & (84) \\
\hline Anti-proliferative & R. davurica & methanol & bark & $\begin{array}{l}\text { MTT colorimetric } \\
\text { assay }\end{array}$ & $\begin{array}{l}\text { Kaempferol (33) exhibited activities against human } \\
\text { cancer cell lines HT-29, SGC-7901 and HePG2 with IC50 } \\
\text { values of } 25.7,13.43 \text { and } 20 \mu \mathrm{g} / \mathrm{mL} \text { respectively, while } \\
\text { the compound apigenin (40) exhibited with IC50 values } \\
19.79,17.76 \text { and } 10.20 \mu \mathrm{g} / \mathrm{mL} \text { respectively }\end{array}$ & (74) \\
\hline Wound healing & R. prinoides & methanol & leaves & $\begin{array}{l}\text { Excision and } \\
\text { incision models in } \\
\text { adult Swiss albino } \\
\text { mice }\end{array}$ & $\begin{array}{l}\text { Treatment with } 5 \% \text { and } 10 \%(\mathrm{w} / \mathrm{w}) \text { methanol extract } \\
\text { ointment exhibited significant wound recovery activities in } \\
\text { both excision and incision models }\end{array}$ & (131) \\
\hline Cytotoxicity & R. frangula & $\begin{array}{l}\text { hydroalco } \\
\text { holic }\end{array}$ & & MTT assay & $\begin{array}{l}\text { Extract exhibited activities against breast cancer cell lines } \\
\text { (MCF-7) with half maximal cytotoxic concentration }\left(\mathrm{CC}_{50}\right) \\
\text { value of } 10 \mathrm{mg} / \mathrm{mL} \text {. }\end{array}$ & (132) \\
\hline Cytotoxicity & R. alaternus & $\begin{array}{l}\text { Ethyl } \\
\text { acetate } \\
\text { and Total } \\
\text { Oligomers }\end{array}$ & leaf & MTT assay & $\begin{array}{l}\text { TOF extract exhibited activities against human chronic } \\
\text { myelogenous } \mathrm{K} 562 \text { and murine leukemia L1210 with } \mathrm{IC}_{50} \\
\text { values of } 75 \mu \mathrm{g} / \mathrm{mL} \text { and } 198 \mu \mathrm{g} / \mathrm{mL} \text { against } \mathrm{K} 562 \text { and } \\
\text { L1210 cells respectively. Similarly, the ethyl acetate }\end{array}$ & (125) \\
\hline
\end{tabular}




\begin{tabular}{|c|c|c|c|c|c|}
\hline & & flavonoids & & $\begin{array}{l}\text { extract showed activities with } \mathrm{IC}_{50} \text { values of } 232 \mu \mathrm{g} / \mathrm{mL} \\
\text { and } 176 \mu \mathrm{g} / \mathrm{mL} \text { respectively }\end{array}$ & \\
\hline Toxicity & R. davurica & ethanol & $\begin{array}{l}\text { Sulforhodamine B } \\
\text { (SRB) } \\
\text { microculture } \\
\text { colorimetric assay }\end{array}$ & $\begin{array}{l}\text { Extract exhibited activities against normal human hepatic } \\
\text { cells ( } \mathrm{L}-02 \text { ) with } \mathrm{IC}_{50} \text { value of } 229.19 \mu \mathrm{g} / \mathrm{mL} \text {. }\end{array}$ & $(84)$ \\
\hline Cytotoxicity & R. alaternus & methanol & Alamar blue assay & $\begin{array}{l}\text { kaempferol 3-O- } \beta \text {-isorhamninoside ( } \mathbf{3 1} \text { ) and rhamnocitrin } \\
3-\mathrm{O}-\beta \text {-isorhamninoside }(\mathbf{3 6}) \text { exhibited activities against } \\
\text { human lymphoblastoid TK6 cells, the compound neither } \\
\text { K3O-ir nor R3O-ir reached } 50 \% \text { inhibition of TK6 cell } \\
\text { proliferation }\end{array}$ & $(75)$ \\
\hline Cytotoxicity & R. nepalensis & methanol & MTT assay & $\begin{array}{l}\text { The isolated compound, prinoidin ( } 23 \text { ) exhibited activities } \\
\text { against KB ( human epidermoid carcinoma of the mouth) } \\
\text { with } \mathrm{IC}_{50} \text { value of } 0.045 \mu \mathrm{M} \text {, which was four times more } \\
\text { potent than the standard, doxorubicin having } \mathrm{IC}_{50} \text { value of } \\
0.2 \mu \mathrm{M}\end{array}$ & (69) \\
\hline Cytotoxicity & R. alaternus & methanol & Trypan blue assay & $\begin{array}{l}\text { extract exhibited activities against human monocytic } \\
\text { leukemia cells (U937) with IC } 50 \text { values of } 6.39 \mu \mathrm{g} / \mathrm{mL} \text {, } \\
\text { which was comparable to IC } C_{50} \text { value of } 2.47 \mathrm{\mu g} / \mathrm{mL} \\
\text { exhibited by taxol the standard drug }\end{array}$ & $(130)$ \\
\hline Anti-tyrosinase & R. nakaharai & Heart wood & $\begin{array}{l}\text { Mushroom } \\
\text { tyrosine inhibitory } \\
\text { assay }\end{array}$ & $\begin{array}{l}\text { 6-methoxysorigenin (12) exhibited activities with } \mathrm{IC}_{50} \\
\text { value of } 42.2 \mu \mathrm{M} \text {, which was twofold inhibitory effect than } \\
\text { the positive control kojil acid having } \mathrm{IC}_{50} \text { value of } 82.1 \mu \mathrm{M}\end{array}$ & $(70)$ \\
\hline Anti-mutagenicity & R. alaternus & aqueous & Ames assay & $\begin{array}{l}\text { The ethyl acetate fraction exhibited against Salmonella } \\
\text { Typhimurium (TA98) strains with a dose of } 250 \mu \mathrm{g} / \mathrm{mL} \\
\text { and } 78 \% \text { inhibition mutagenicity }\end{array}$ & (124) \\
\hline Antigenotoxic & R. alaternus & methanol leaf & SOS chromo test & $\begin{array}{l}\text { kaempferol 3-O- } \beta \text {-isorhamninoside (31) and rhamnocitrin } \\
3-O-\beta \text {-isorhamninoside (36) on } E \text {. coli PQ37 at different } \\
\text { concentration }(1,5 \text { and } 10 \mu \mathrm{g} / \mathrm{mL}) \text { showed } \\
\text { antigenotoxicity activities }\end{array}$ & $(73)$ \\
\hline Antigenotoxic & R. alaternus & methanol leaf & Comet assay & $\begin{array}{l}\text { Kaempferol 3-O- } \beta \text {-isorhamninoside (31) and rhamnocitrin } \\
3-O-\beta \text {-isorhamninoside (36) exhibited activities against } \\
\text { human lymphoblastoid cells TK6 at the same tested } \\
\text { concentration, the total DNA damage induced by K3O-ir } \\
\text { and R3O-ir showed no significant difference was detected }\end{array}$ & $(126)$ \\
\hline
\end{tabular}




\section{CONCLUSION}

Traditional medicine continues as an alternative care available for the majority of the developing countries due to its intrinsic qualities, unique and holistic approaches as well as its accessibility and affordability. The present review endeavors to provide a comprehensive and up to date compilation of documented traditional medicinal uses, phytochemicals and pharmacological activities of the genus and provided valuable information in support of its uses as an alternative medicine for future healthcare practice. Phytochemicals including anthraquinones and flavonoids are the most dominant compounds reported from the genus of which polyphenols were abundant with tremendous antioxidant, wound healing and antiinflammatory activities. The genus afforded exemplary drug leads such as 6methoxysorigenin (12) and prinoidin (23) with anti-tyrosinase and cytotoxicity as well as antioxidant drug leads such as Rhamnetin-3-O- $\beta$ isorhamninoside (37) and isotorachrysone (55). Nevertheless, more attention should be paid to the genus considering its wide spectrum of pharmacological properties. Further investigation should be conducted to evaluate promising cruds extracts as well as compounds in search for new drug candidates.

\section{CONFLICT OF INTEREST}

The authors declare that there is no conflict of interest.

\section{ACKNOWLEDGMENT}

Authors express their gratitude to Adama Science and Technology University for providing access to various journal databases.

\section{REFERENCES}

1. Nigussie G. A review on traditionally used medicinal plants for scabies therapy in Ethiopia. ADV TRADIT MED (ADTM). 2021 Jun;21(2):199208. $\leq$ DOI $>$.

2. Nigussie G, Ibrahim F, Neway S. A Phytopharmacological Review on a Medicinal Plant: Cordia africana Lam. J Trop Pharm Chem. 2021 Jan $18 ; 5(3): 254-63$. <DOI>.

3. Anonymous. Plants of the World online [Internet]. 2021. <URL>.

4. Quattrocchi U. CRC world dictionary of medicinal and poisonous plants [Internet]. CRC Press; 2014 [cited 2021 Jul 29]. $\leq$ URL $>$.
5. Dafni A, Yaniv Z, Palevitch D. Ethnobotanical survey of medicinal plants in northern Israel. Journal of Ethnopharmacology. 1984 May; $10(3): 295-310$. $\leq$ DOI $>$.

6. Watson RR, Preedy VR, editors. Arab herbal medicine. In: Botanical medicine in clinical practice. Wallingford, UK; Cambridge, MA: CABI; 2008. p. 31-9. ISBN: 978-1-84593-413-2.

7. Moerman DE. Native American ethnobotany. Portland, Or: Timber Press; 1998. 927 p. ISBN: 978-0-88192-453-4.

8. Zevin IV, Altman N, Zevin LV. A Russian herbal: traditional remedies for health and healing [Internet]. Rochester, Vt.: Healing Arts Press; 1997 [cited 2021 Jul 29]. ISBN: 978-0-89281-5494.

9. Watson RR, Preedy VR, editors. Botanical medicine in clinical practice. Wallingford, UK; Cambridge, MA: CABI; 2008. 915 p. ISBN: 978-184593-413-2.

10. Page L. Detoxification: all you need to know to recharge, renew and rejuvenate your body, mind and spirit! Carmel Valley, CA: Traditional Wisdom, Inc.; 2002. ISBN: 978-1-884334-54-2.

11. Xutian S. Handbook of traditional chinese medicine. Singapore: World Scientific; 2014. ISBN: 978-981-4571-34-0.

12. Tucakov J. [Ethnophytotherapy of diabetes. Critical view on the use of medicinal plant extracts in our national medicine in the treatment of diabetes mellitus]. Srp Arh Celok Lek. 1978 Feb;106(2):159-73.

13. Chhabra S, Uiso F. Antibacterial activity of some Tanzanian plants used in traditional medicine. Fitoterapia. 1991;62(6):499-503.

14. Abdelkrim B, Khaled K, Miloud S, Imane D, Kheira A. Hepatoprotective effects of the decoction and macerated leaves of Rhamnus alaternus $L$. on rats exposed to carbon tetrachloride. J Pharmacognosy Phytother. 2015 Oct $31 ; 7(10): 253-62$. <DOI .

15. Amabye TG. Evaluation of Phytochemical, Chemical Composition, Antioxidant and Antimicrobial Screening Parameters of Rhamnus prinoides (Gesho) Available in the Market of Mekelle, Tigray, Ethiopia. Nat Prod Chem Res [Internet]. 2016;04(01):1000198, 1-6. <DOI>.

16. Montalvo A, Riordan E, Beyers J. Plant profile for Rhamnus crocea and Rhamnus ilicifolia. Native 
Plant Recommendations for Southern California Ecoregions. 2020;

17. Evans WC, Evans D. Trease and Evans pharmacognosy. Edinburgh; London; New York: Saunders Elsevier; 2009. ISBN: 978-0-7020-29332.

18. Kubitzki K. Flowering plants - Dicotyledons: Celastrales, oxalidales, rosales, cornales, ericales [Internet]. 2004 [cited 2021 Jul 29]. ISBN: 978-3662-07257-8.

19. Boukef K. Rhamnus alaternus. Essaydali. 2001;81:34-5.

20. Benarba B. Medicinal plants used by traditional healers from South-west Algeria: an ethnobotanical study. J Intercult Ethnopharmacol. 2016;5(4):320. <DOI>.

21. Nazim B, Houari T, Ismail B. Ethnobotanical Survey of Some Plants Used in Tessala Region, Algeria. Current Perspectives on Medicinal and Aromatic Plants (CUPMAP). 2020 Apr 1;3(1):1824. $\leq \mathrm{DOI}>$.

22. Miara MD, Bendif $H$, Rebbas $K$, Rabah $B$, Hammou MA, Maggi F. Medicinal plants and their traditional uses in the highland region of Bordj Bou Arreridj (Northeast Algeria). Journal of Herbal Medicine. 2019 Jun; 16:100262. <DOI>.

23. Calvo MI, Cavero RY. Medicinal plants used for cardiovascular diseases in Navarra and their validation from Official sources. Journal of Ethnopharmacology. $2014 \quad$ Nov;157:268-73. $\leq \mathrm{DOI}>$.

24. Menendez-Baceta G, Aceituno-Mata L, Molina M, Reyes-García V, Tardío J, Pardo-de-Santayana M. Medicinal plants traditionally used in the northwest of the Basque Country (Biscay and Alava), Iberian Peninsula. Journal of Ethnopharmacology. 2014 Feb;152(1):113-34. $\leq$ DOI $>$.

25. Leto C, Tuttolomondo T, La Bella S, Licata M. Ethnobotanical study in the Madonie Regional Park (Central Sicily, Italy)-Medicinal use of wild shrub and herbaceous plant species. Journal of Ethnopharmacology. 2013 Mar;146(1):90-112. $\leq$ DOI $>$.

26. Akerreta S, Cavero RY, López V, Calvo MI. Analyzing factors that influence the folk use and phytonomy of 18 medicinal plants in Navarra. J Ethnobiology Ethnomedicine. 2007 Dec;3(1):16. $\leq$ DOI $>$.
27. Fortini $P$, Di Marzio $P$, Guarrera $P M$, Iorizzi $M$. Ethnobotanical study on the medicinal plants in the Mainarde Mountains (central-southern Apennine, Italy). Journal of Ethnopharmacology. 2016 May; 184:208-18. <DOI>.

28. Redzic S. Wild medicinal plants and their usage in traditional human therapy (Southern Bosnia and Herzegovina, W. Balkan). Journal of Medicinal Plants Research. 2010;4(11):1003-27. <URL>.

29. Altundag E, Ozturk M. Ethnomedicinal studies on the plant resources of east Anatolia, Turkey. Procedia - Social and Behavioral Sciences. 2011;19:756-77. <DOI>.

30. Jarić S, Kostić O, Mataruga Z, Pavlović D, Pavlović $M$, Mitrović $M$, et al. Traditional woundhealing plants used in the Balkan region (Southeast Europe). Journal of Ethnopharmacology. 2018 Jan;211:311-28. $\leq$ DOI $>$.

31. Jarić $S$, Popović $Z$, Mačukanović-Jocić $M$, Djurdjević L, Mijatović M, Karadžić B, et al. An ethnobotanical study on the usage of wild medicinal herbs from Kopaonik Mountain (Central Serbia). Journal of Ethnopharmacology. 2007 Apr;111(1):160-75. <DOI>.

32. Šamec D, Kremer D, Grúz J, Jurišić Grubešić R, Piljac-Žegarac J. Rhamnus intermedia Steud. et Hochst.-a new source of bioactive phytochemicals. Croatica Chemica Acta. 2012;85(2):125-9. $\leq \mathrm{URL}>$.

33. Šarić-Kundalić B, Dobeš C, Klatte-Asselmeyer V, Saukel J. Ethnobotanical survey of traditionally used plants in human therapy of east, north and north-east Bosnia and Herzegovina. Journal of Ethnopharmacology. 2011 Feb;133(3):1051-76. $\leq \mathrm{DOI}>$.

34. Menković N, Šavikin $K$, Tasić $S$, Zdunić $G$, Stešević D, Milosavljević S, et al. Ethnobotanical study on traditional uses of wild medicinal plants in Prokletije Mountains (Montenegro). Journal of Ethnopharmacology. 2011 Jan;133(1):97-107. $<$ DOI $>$.

35. Mohagheghzadeh A, Faridi $P$, Shams-Ardakani M, Ghasemi Y. Medicinal smokes. Journal of Ethnopharmacology. 2006 Nov;108(2):161-84. $\leq$ DOI $>$.

36. Bozyel ME, Merdamert Bozyel E, Canli K, Altuner EM. Türk Geleneksel Tıbbında Tıbbi Bitkilerin Antikanser Kullanımları. Kahramanmaraş Sütçü İmam Üniversitesi Tarım ve Doğa Dergisi. 2019 Dec 31;22(Suppl2):465-84. <DOI>. 
37. Purkayastha J, Nath SC, Islam M. Ethnobotany of medicinal plants from Dibru-Saikhowa Biosphere Reserve of Northeast India. Fitoterapia. 2005 Jan;76(1):121-7. <DOI $>$. .

38. Fakir H, Korkmaz M, Güller B. Medicinal Plant Diversity of Western Mediterrenean Region in Turkey. Journal of Applied Biological Sciences. 2019;3(2):33-43. <URL>. .

39. Maleki T, Akhani H. Ethnobotanical and ethnomedicinal studies in Baluchi tribes: A case study in Mt. Taftan, southeastern Iran. Journal of Ethnopharmacology. 2018 May;217:163-77. $\leq$ DOI $>$.

40. Nankaya J, Nampushi J, Petenya S, Balslev H. Ethnomedicinal plants of the Loita Maasai of Kenya. Environ Dev Sustain. 2020 Mar;22(3):2569-89. <DOI>..

41. Muthee JK, Gakuya DW, Mbaria JM, Kareru PG, Mulei CM, Njonge FK. Ethnobotanical study of anthelmintic and other medicinal plants traditionally used in Loitoktok district of Kenya. Journal of Ethnopharmacology. 2011 Apr;135(1):15-21. <DOI>.

42. Nankaya J, Gichuki N, Lukhoba C, Balslev H. Medicinal Plants of the Maasai of Kenya: A Review. Plants. 2019 Dec 27;9(1):44. <DOI>. .

43. Mesfin F, Seta T, Assefa A. An ethnobotanical study of medicinal plants in Amaro Woreda, Ethiopia. Ethnobotany Research and Applications. 2014;12:341-54.

44. Elgorashi E. Screening of medicinal plants used in South African traditional medicine for genotoxic effects. Toxicology Letters. 2003 Jul 20;143(2):195-207. <DOI>..

45. Seleteng Kose L, Moteetee A, Van Vuuren S. Ethnobotanical survey of medicinal plants used in the Maseru district of Lesotho. Journal of Ethnopharmacology. 2015 Jul;170:184-200. $\leq$ DOI $>$.

46. Njoroge GN, Bussmann RW. Traditional management of ear, nose and throat (ENT) diseases in Central Kenya. J Ethnobiology Ethnomedicine. 2006 Dec;2(1):54. <DOI>. .

47. Kidane $B$, van Andel $T$, van der Maesen $L$, Asfaw $Z$. Use and management of traditional medicinal plants by Maale and Ari ethnic communities in southern Ethiopia. J Ethnobiology Ethnomedicine. 2014;10(1):46. <DOI>. .

48. Teka A, Asfaw Z, Demissew S, Van Damme P. Traditional uses of medicinal plants practiced by the indigenous communities in Gurage Zone, south central Ethiopia. Ethnobotany Research and Applications. 2020;19:1-31.

49. Tamene S. Ethnobotanical study of indigenous knowledge on medicinal plant uses and threatening factors around the Malga District, Southern Ethiopia. International Journal of Biodiversity and Conservation. 2020;12(3):215-26.

50. Bitew H, Gebregergs $H$, Tuem KB, Yeshak MY. Ethiopian medicinal plants traditionally used for wound treatment: a systematic review. Ethiopian Journal of Health Development. 2019;33(2).

51. Araya S, Abera B, Giday M. Study of plants traditionally used in public and animal health management in Seharti Samre District, Southern Tigray, Ethiopia. J Ethnobiology Ethnomedicine. 2015 Dec;11(1):22. <DOI>. .

52. Teklehaymanot T, Giday M. Ethnobotanical study of medicinal plants used by people in Zegie Peninsula, Northwestern Ethiopia. J Ethnobiology Ethnomedicine. 2007 Dec;3(1):12. <DOI>.

53. Asmare T, Yilkal B, Mekuannint T, Yibeltal A. Traditional medicinal plants used to treat maternal and child health illnesses in Ethiopia: an ethnobotanical approach. J Tradit Med Clin Natur. 2018;7(277):2.

54. Tabuti JRS, Kukunda CB, Waako PJ. Medicinal plants used by traditional medicine practitioners in the treatment of tuberculosis and related ailments in Uganda. Journal of Ethnopharmacology. 2010 Jan;127(1):130-6. <DOI>.

55. Mesfin K, Tekle G, Tesfay T. Ethnobotanical study of traditional medicinal plants used by indigenous people of Gemad District, Northern Ethiopia. Journal of Medicinal Plants Studies. 2013;1(4):32-7. <URL>. .

56. Siyum D, Woyessa D. Assessment of bacteriological quality and traditional treatment methods of water-borne diseases among well water users in Jimma Town, South West Ethiopia. ARPN J Ag \& Bio Sci. 2013;8:477-86.

57. Abdeta D, Amante M, Tamiru Y. Survey on Ethno Botany and Medicinal Animals at Sayo and Hawa Gelan Districts of Kelem Wollega Zone, Western Ethiopia. preventive medicine. 2020;28(2):21408-20.

58. Kamanja I, Mbaria J, Gathumbi P, Mbaabu M, Lanyasunya A, Gakuya D, et al. Medicinal plants used in the management of sexually transmitted infections by the Samburu Community Kenya. Int J Pharm Res. 2015;7:44-52. 
59. Amuka O, Mbugua PK, Okemo PO. Ethnobotanical survey of selected medicinal plants used by the Ogiek communities in Kenya against microbial infections. Ethnobotany Research and Applications. 2014;12:627-41.

60. Garedew B, Bizuayehu B. A Review on Ethnobotanical Study of Traditional Medicinal Plants Used for Treatment of Liver Problems in Ethiopia. EJMP. 2018 Dec 1;26(1):1-18. <DOI>. .

61. Malik ZA, Bhat JA, Ballabha R, Bussmann RW, Bhatt $A B$. Ethnomedicinal plants traditionally used in health care practices by inhabitants of Western Himalaya. Journal of Ethnopharmacology. 2015 Aug;172:133-44. $\leq$ DOI $>$.

62. Sharma $P$, Samant S. Diversity, distribution and indigenous uses of medicinal plants in Parbati Valley of Kullu district in Himachal Pradesh, Northwestern Himalaya. Asian J Adv Basic Sci. 2014;2:77-98.

63. Josabad Alonso-Castro A, Jose MaldonadoMiranda J, Zarate-Martinez A, Jacobo-Salcedo $M$ del R, Fernández-Galicia C, Alejandro FigueroaZuñiga $L$, et al. Medicinal plants used in the Huasteca Potosina, México. Journal of Ethnopharmacology. 2012 Aug;143(1):292-8. $\leq \mathrm{DOI}>$.

64. Kiringe JW. A survey of traditional health remedies used by the Maasai of Southern Kaijiado District, Kenya. Ethnobotany Research and Applications. 2006;4:061-74. $\leq U R L>$. .

65. Ajaib $M$, Khan $Z$, Khan $N$, Wahab $M$. Ethnobotanical studies on useful shrubs of district Kotli, Azad Jammu \& Kashmir, Pakistan. Pak J Bot. 2010;42(3):1407-15. <URL>. .

66. Phondani $\mathrm{P}$, Maikhuri $\mathrm{R}$, Bisht N. Medicinal plants used in the health care system practiced by traditional Vaidyas in Alaknanda catchment of Uttarakhand, India. Ethnobotanical Leaflets. 2009;2009(12):4. <URL>. .

67. Rokaya MB, Münzbergová Z, Timsina B. Ethnobotanical study of medicinal plants from the Humla district of western Nepal. Journal of Ethnopharmacology. 2010 Aug;130(3):485-504. $\leq$ DOI $>$. .

68. Rana TS, Datt B. E THNOBOTANICAL O BSERVATION AMONG J AUNSARIS OF J AUNSAR -B AWAR , D EHRA D UN (U.P.), I NDIA. International Journal of Pharmacognosy. 1997 Jan;35(5):371-4. $\leq$ DOI $>$. .
69. Mai LP, Guéritte $F$, Dumontet $V$, Tri MV, Hill $B$, Thoison $O$, et al. Cytotoxicity of Rhamnosylanthraquinones and Rhamnosylanthrones from Rhamnus nepalensis. J Nat Prod. 2001 Sep;64(9):1162-8. <DOI>. .

70. Lu T-M, Ko H-H. A new anthraquinone glycoside from Rhamnus nakaharai and antityrosinase effect of 6-methoxysorigenin. Natural Product Research. 2016 Dec 1;30(23):2655-61. $\leq$ DOI $>$. .

71. Liao J-C, Deng J-S, Chiu C-S, Huang S-S, Hou W-C, Lin W-C, et al. Chemical Compositions, AntiInflammatory, Antiproliferative and RadicalScavenging Activities of Actinidia callosa var. ephippioides. Am J Chin Med. 2012 Jan;40(05):1047-62. <DOI>. .

72. Ammar RB, Bhouri W, Sghaier MB, Boubaker J, Skandrani I, Neffati A, et al. Antioxidant and free radical-scavenging properties of three flavonoids isolated from the leaves of Rhamnus alaternus $\mathrm{L}$. (Rhamnaceae): A structure-activity relationship study. Food Chemistry. 2009 Sep;116(1):258-64. $\leq \mathrm{DOI}>$.

73. Bhouri W, Sghaier MB, Kilani S, Bouhlel I, Dijoux-Franca M-G, Ghedira K, et al. Evaluation of antioxidant and antigenotoxic activity of two flavonoids from Rhamnus alaternus $L$. (Rhamnaceae): Kaempferol 3-O- $\beta$-isorhamninoside and rhamnocitrin 3-O- $\beta$-isorhamninoside. Food and Chemical Toxicology. 2011 May;49(5):1167-73. $\leq \mathrm{DOI}$. .

74. Chen G, Wu J, Li N, Guo M. Screening for antiproliferative and anti-inflammatory components from Rhamnus davurica Pall. using bio-affinity ultrafiltration with multiple drug targets. Anal Bioanal Chem. 2018 Jun;410(15):3587-95. $\leq \mathrm{DOI}$. .

75. Bhouri W, Bouhlel I, Boubaker J, Kilani S, Ghedira K, Ghedira LC. Induction of apoptosis in human lymphoblastoid cells by kaempferol 3-O- $\beta$ isorhamninoside and rhamnocitrin 3-O- $\beta$ isorhamninoside from Rhamnus alaternus $\mathrm{L}$. (Rhamnaceae): Induction of apoptosis in human lymphoblastoid cells. Cell Proliferation. 2011 Jun;44(3):283-90. <DOI >. .

76. Raja WRT, Antony S, Entomology Research Institute, Loyola College, Chennai - 600034, India, Pachaiyappan SK, Entomology Research Institute, Loyola College, Chennai - 600034, India, Amalraj $\mathrm{J}$, et al. Antibacterial Activity study of Musizin isolated from Rhamnus wightii Wight \& Arn. Bioinformation. 2018 Dec 31;14(9):511-20. $<$ DOI $>$. . 
77. Carranza MG, Sevigny MB, Banerjee D, FoxCubley L. Antibacterial activity of native California medicinal plant extracts isolated from Rhamnus californica and Umbellularia californica. Ann Clin Microbiol Antimicrob. 2015 Dec;14(1):29. <DOI>.

78. Bribi N. Pharmacological activity of alkaloids: a review. Asian Journal of Botany. 2018;1:1-6.

79. Lin C-N, Chung M-I, Lu C-M. Anthraquinones from Rhamnus formosana. Phytochemistry. 1990;29(12):3903-5. <DOI>..

80. Ben Ammar R, Miyamoto T, Chekir-Ghedira L, Ghedira K, Lacaille-Dubois M-A. Isolation and identification of new anthraquinones from Rhamnus alaternus $L$ and evaluation of their free radical scavenging activity. Natural Product Research. 2019 Jan 17;33(2):280-6. <DOI>.

81. Hernández-Carlos $B$, Fernández $R$, Delgado $F$, Tamariz J, Zepeda LG, Joseph-nathan P. The Chemical Constituents of Rhamnus serrata var. serrata. Natural Product Letters. 1996 Feb;8(1):39-42. <DOI >..

82. Moussi K, Nayak B, Perkins LB, Dahmoune F, Madani K, Chibane M. HPLC-DAD profile of phenolic compounds and antioxidant activity of leaves extract of Rhamnus alaternus L. Industrial Crops and Products. 2015 Nov;74:858-66. <DOI>. .

83. Wang L, Fan S, Wang X, Wang X, Yan X, Shan $D$, et al. Physicochemical Aspects and Sensory Profiles as Various Potential Factors for Comprehensive Quality Assessment of Nü-Er-Cha Produced from Rhamnus heterophylla Oliv. Molecules. 2019 Sep 4;24(18):3211. <DOI>. .

84. Chen G, Li X, Saleri F, Guo M. Analysis of Flavonoids in Rhamnus davurica and Its Antiproliferative Activities. Molecules. 2016 Sep 23;21(10):1275. <DOI $>$.

85. Abegaz BM, Kebede T. Geshoidin: A bitter principle of Rhamnus prinoides and other constituents of the leaves. Bulletin of the Chemical Society of Ethiopia. 1995;9(2):107-14. <URL>. .

86. Kosalec I, Kremer D, Locatelli M, Epifano F, Genovese S, Carlucci G, et al. Anthraquinone profile, antioxidant and antimicrobial activity of bark extracts of Rhamnus alaternus, R. fallax, R. intermedia and R. pumila. Food Chemistry. 2013 Jan;136(2):335-41. <DOI>. .

87. Gonçalves RS, Silva EL, Hioka N, Nakamura CV, Bruschi ML, Caetano W. An optimized protocol for anthraquinones isolation from Rhamnus frangula $L$.
Natural Product Research. 2018 Feb 1;32(3):3669. $\leq \mathrm{DOI}>$. .

88. Moreira TF, Sorbo JM, Souza F de O, Fernandes BC, Ocampos FMM, de Oliveira DMS, et al. Emodin, Physcion, and Crude Extract of Rhamnus sphaerosperma var. pubescens Induce Mixed Cell Death, Increase in Oxidative Stress, DNA Damage, and Inhibition of AKT in Cervical and Oral Squamous Carcinoma Cell Lines. Oxidative Medicine and Cellular Longevity. 2018 Jul 3;2018:1-18. <DOI $>$. .

89. Genovese S, Tammaro F, Menghini L, Carlucci G, Epifano F, Locatelli M. Comparison of three different extraction methods and HPLC determination of the anthraquinones aloeemodine, emodine, rheine, chrysophanol and physcione in the bark of Rhamnus alpinus $L$. (Rhamnaceae): Determination of Anthraquinones in Rhamnus Alpinus. Phytochem Anal. 2010 May;21(3):261-7. <DOI $>$.

90. Locatelli M, Genovese S, Carlucci G, Kremer D, Randic M, Epifano F. Development and application of high-performance liquid chromatography for the study of two new oxyprenylated anthraquinones produced by Rhamnus species. Journal of Chromatography A. 2012 Feb;1225:113-20. $\leq \mathrm{DOI}$. .

91. Locatelli M, Tammaro F, Menghini L, Carlucci G, Epifano F, Genovese S. Anthraquinone profile and chemical fingerprint of Rhamnus saxatilis $L$. from Italy. Phytochemistry Letters. 2009 Nov;2(4):2236. $\leq \mathrm{DOI}>$.

92. Abegaz B, Dagne E. Anthracene derivatives of Rhamnus prinoides. Bulletin of the Chemical Society of Ethiopia. 1988;2(1):15-20. $\leq U R L>$. .

93. Abegaz BM, Peter MG. Emodin and emodinanthrone rhamnoside acetates from fruits of Rhamnus prinoides. Phytochemistry. 1995 Aug;39(6):1411-4. <DOI>..

94. Hamed MM, Refahy LA, Abdel-Aziz MS. Evaluation of antimicrobial activity of some compounds isolated from Rhamnus cathartica $L$. Orient J Chem. 2015;31(2):1133-40.

95. Sharp H, Latif Z, Bartholomew B, Thomas D, Thomas B, Sarker SD, et al. Emodin and syringaldehyde from Rhamnus pubescens (Rhamnaceae). Biochemical systematics and ecology. $2001 ; 29(1): 113-5$.

96. Zeouk I, Ouedrhiri W, Jiménez IA, LorenzoMorales J, Bazzocchi IL, Bekhti K. Intra-combined antioxidant activity and chemical characterization of three fractions from Rhamnus alaternus extract: 
Mixture design. Industrial Crops and Products. 2020 Feb;144:112054. <DOI>. .

97. Dwivedi SPD, Pandey VB, Shah AH, Rao YB. Chemical constituents ofRhamnus procumbens and pharmacological actions of emodin. Phytother Res. 1988 Mar;2(1):51-3. <DOI>. .

98. Ben Ghezala H, Chaouali N, Gana I, Snouda S, Nouioui A, Belwaer I, et al. Toxic Effects of Rhamnus alaternus: A Rare Case Report. Case Reports in Emergency Medicine. 2015;2015:1-5. $\leq$ DOI $>$.

99. Epifano F, Genovese S, Kremer D, Randic M, Carlucci G, Locatelli M. Re-investigation of the Anthraquinone Pool of Rhamnus spp.: Madagascin from the Fruits of Rhamnus cathartica and $R$. intermedia. Natural Product Communications. 2012 Aug;7(8):1934578X1200700. <DOI>. .

100. Cuoco G, Mathe C, Vieillescazes C. New emodin arabinoside acetates from fruits of Rhamnus alaternus. Current Topics in Phytochemistry, Volume 10. 2011;61-6.

101. Coskun M, Toshiko S, Hori K, Saiki Y, Tanker M. Anthraquinone glycosides from Rhamnus

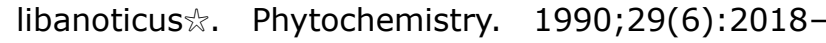
20. $\leq$ DOI $>$. .

102. Coskun M, Tanker N, Sakushima A, Kitagawa $S$, Nishibe $S$. An anthraquinone glycoside from Rhamnus pallasii. Phytochemistry. 1984 Jan;23(7):1485-7. <DOI>. .

103. Bezabih M, Abegaz BM. Glucofrangulin A diacetate from the fruits of Rhamnus prinoids. Bulletin of the Chemical Society of Ethiopia. 1998;12(1):45-8. $\leq \mathrm{URL}>$. .

104. Lin C-N, Chung M-I, Gan K-H, Lu C-M. Flavonol and anthraquinone glycosides from Rhamnus formosana. Phytochemistry. 1991 Jan;30(9):3103-6. <DOI >. .

105. Özipek M, Çaliş İ, Ertan $M$, Rüedi P. Rhamnetin 3-p-coumaroylrhamninoside from Rhamnus petiolaris. Phytochemistry. 1994 Jan;37(1):249-53. <DOI>. .

106. Cuoco G, Mathe C, Vieillescazes C. Liquid chromatographic analysis of flavonol compounds in green fruits of three Rhamnus species used in Stil de grain. Microchemical Journal. 2014 Jul;115:130-7. <DOI>. .

107. Payá M, Máñez S, Villar A. Flavonoid Constituents of Rhamnus lycioides L. Zeitschrift für Naturforschung C. 1986 Dec 1;41(11-12):976-8. $\leq \mathrm{DOI}>$.
108. Sakushima A, Coşkun M, Hisada S, Nishibe S. Flavonoids from Rhamnus pallasii. Phytochemistry. 1983 Jan;22(7):1677-8. <DOI>. .

109. Marzouk MS, El-Toumy SAA, Merfort I, Nawwar MAM. Polyphenolic metabolites of Rhamnus disperma. Phytochemistry. 1999 Nov;52(5):943-6. <DOI>..

110. Máñez $S$, Payá $M$, Terencio $C$, Villar $A$. Flavonoids of Rhamnus lycioides; Part 2. Planta Med. 1988 Apr;54(02):187-8. <DOI>. .

111. Hsiao G, Ko F-N, Lin C-N, Teng C-M. Antioxidant properties of isotorachrysone isolated from Rhamnus nakaharai. Biochimica et Biophysica Acta (BBA) - Protein Structure and Molecular Enzymology. 1996 Nov;1298(1):119-30. <DOI>. .

112. Sut S, Dall'Acqua S, Ibrahime Sinan K, Bene K, Kumar G, Fawzi Mahomoodally M, et al. Cola caricifolia (G.Don) K. Schum and Crotalaria retusa L. from Ivory Coast as sources of bioactive constituents. Industrial Crops and Products. 2020 May; 147:112246. <DOI $>$. .

113. Campbell M, Zhao W, Fathi R, Mihreteab M, Gilbert ES. Rhamnus prinoides (gesho): A source of diverse anti-biofilm activity. Journal of Ethnopharmacology. 2019 Sep;241:111955. $\leq \mathrm{DOI}>$.

114. Chouitah O, Meddah B, Aoues A. Analysis of the Chemical Composition and Antimicrobial Activity of the Essential Oil from Rhamnus alaternus. Journal of Biologically Active Products from Nature. 2012 Jan;2(5):302-6. <DOI>. .

115. Thakur C, Prasad B. Antiinflammatory Activity of Stem Bark of Rhamnus purpureus. Int J Adv Microbiol Health Res. 2019;3(1):21-8.

116. Chen G-L, Munyao Mutie F, Xu Y-B, Saleri FD, Hu G-W, Guo M-Q. Antioxidant, Anti-inflammatory Activities and Polyphenol Profile of Rhamnus prinoides. Pharmaceuticals. 2020 Mar 26;13(4):55. $\leq \mathrm{DOI}>$. .

117. Molla $Y$, Nedi T, Tadesse G, Alemayehu $H$, Shibeshi W. Evaluation of the in vitro antibacterial activity of the solvent fractions of the leaves of Rhamnus prinoides L'Herit (Rhamnaceae) against pathogenic bacteria. BMC Complement Altern Med. 2016 Dec;16(1):287. <DOI>. .

118. Ben Ammar R, Kilani S, Bouhlel I, Skandrani I, Naffeti A, Boubaker J, et al. Antibacterial and cytotoxic activities of extracts from (Tunisian)Rhamnus alaternus (Rhamnaceae). Ann Microbiol. 2007 Sep;57(3):453-60. <DOI>. . 
119. Koch A, Tamez P, Pezzuto J, Soejarto D. Evaluation of plants used for antimalarial treatment by the Maasai of Kenya. Journal of Ethnopharmacology. 2005 Oct;101(1-3):95-9. $\leq$ DOI $>$. .

120. Bosire K. An investigation of a traditional herbal therapy used to treat malaria in Kisii [Internet] [Master of Science Thesis]. [Nairobi, Kenya]: University of Nairobi; 2003. $\leq$ URL $>$. .

121. Gebru M. Phytochemical and antiplasmodial investigation of rhamnus prinoides and kniphofia foliosa [Internet] [Master of Science Thesis]. [Nairobi, Kenya]: University of Nairobi; 2010. $\leq \mathrm{URL}>$.

122. Muregi FW, Ishih A, Suzuki T, Kino H, Amano T, Mkoji GM, et al. In Vivo antimalarial activity of aqueous extracts from Kenyan medicinal plants and their Chloroquine (CQ) potentiation effects against a blood-induced CQ-resistant rodent parasite in mice. Phytother Res. 2007 Apr;21(4):337-43. <DOI>..

123. Rocchetti G, Miras-Moreno MB, Zengin G, Senkardes I, Sadeer NB, Mahomoodally MF, et al. UHPLC-QTOF-MS phytochemical profiling and in vitro biological properties of Rhamnus petiolaris (Rhamnaceae). Industrial Crops and Products. 2019 Dec;142:111856. <DOI>.

124. Ammar RB, Sghaier MB, Boubaker J, Bhouri W, Naffeti A, Skandrani I, et al. Antioxidant activity and inhibition of aflatoxin B1-, nifuroxazide-, and sodium azide-induced mutagenicity by extracts from Rhamnus alaternus L. Chemico-Biological Interactions. $2008 \mathrm{Jul} ; 174(1): 1-10$. $\leq \mathrm{DOI}>$. .

125. Ben Ammar R, Kilani S, Bouhlel I, Ezzi L, Skandrani I, Boubaker J, et al. Antiproliferative, Antioxidant, and Antimutagenic Activities of Flavonoid-Enriched Extracts from (Tunisian) Rhamnus alaternus L.: Combination with the Phytochemical Composition. Drug and Chemical Toxicology. 2008 Jan;31(1):61-80. <DOI>. .

126. Bhouri W, Boubaker J, Kilani S, Ghedira K, Chekir-Ghedira L. Flavonoids from Rhamnus alaternus L. (Rhamnaceae): Kaempferol 3-O- $\beta$ isorhamninoside and rhamnocitrin 3-O- $\beta$ isorhamninoside protect against DNA damage in human lymphoblastoid cell and enhance antioxidant activity. South African Journal of Botany. 2012 May;80:57-62. <DOI>..

127. Chaouche TM, Haddouchi F, Boudjemai O, Ghellai I. Antioxidant and hemolytic activity of Ziziphus jujuba Mill and Rhamnus alaternus $L$ (Rhamnaceae) extracts from Algeria. Activité antioxydante et hémolytique des extraits de
Ziziphus jujuba Mill et Rhamnus alaternus (Rhamnaceae) d'Algérie. Bulletin de la Société Royale des Sciences de Liège [Internet]. 2020; $\leq \mathrm{URL}>$. .

128. Mazhar F, Jahangir M, Abbasi MA, Ilyas SA, Khalid $F$, Khanum $R$, et al. Rhamnus triquetra: $A$ Valuable Source of Natural Antioxidants to Shield from Oxidative Stress. Asian Journal of Chemistry. $2013 ; 25(15): 8569-73$.

129. Boussahel S, Dahamna S, Ruberto G, Siracusa L, Harzallah D. Phytochemical Study and Antioxidant Activities of Leaves Extracts from Rhamnus alaternus L. Pharmacognosy Communications. $2013 ; 3(1): 46-53$.

130. Speciale A, Ferlazzo G, Harzallah D, Boussahel S, Dahamna S, Amar Y, et al. Flavonoid profile, antioxidant and cytotoxic activity of different extracts from Algerian Rhamnus alaternus L. bark. Phcog Mag. 2015;11(42):102. <DOI>.

131. Tessema Z, Molla Y. Evaluation of the wound healing activity of the crude extract of root bark of Brucea antidysentrica, the leaves of Dodonaea angustifolia and Rhamnus prinoides in mice. Heliyon. 2021 Jan;7(1):e05901. <DOI>.

132. Ahmadi R, Hatami F, Molseghi M. The Effects of Co-administration of Frangula alnus and Rhamnus frangula Extract on Breast Cancer Cells in Cell Culture. In: BIOES-16 [Internet]. 2016. p. 78-80. $\leq \mathrm{URL}>$. .

133. Tacherfiout $M$, Petrov PD, Mattonai $M$, Ribechini $E$, Ribot $J$, Bonet $M L$, et al. Antihyperlipidemic effect of a Rhamnus alaternus leaf extract in Triton-induced hyperlipidemic rats and human HepG2 cells. Biomedicine \& Pharmacotherapy. 2018 May;101:501-9. <DOI>.. 
Nigussie G, Melak H, Endale M. JOTCSA. 2021; 8(3): 899-932.

REVIEW ARTICLE 